\title{
PRIORITY AS PATHOLOGY: THE PARI PASSU MYTH
}

\author{
RizWAan JAMEel MOKaL*
}

\section{INTRODUCTION}

MANY a challenge to the different priorities accorded to different types of claim in a company's insolvency begins with an incantation of the pari passu principle. Finch states (on the second page of her encyclopaedic recent study on secured credit): "The normal rule in a corporate insolvency is that all creditors are treated on an equal footing-pari passu-and share in insolvency assets pro rata according to their pre-insolvency entitlements or the sums they are owed. Security avoids the effects of pari passu distribution by creating rights that have priority over the claims of unsecured creditors."1 Bridge sees an inherent tension between the "two fundamental principles of credit and insolvency law", that of the freedom of contract which allows one to bargain for priority, and the mandatory pari passu principle. $^{2}$ And Cranston, after considering and discounting lesser objections to the existence of secured credit, concludes that "there are other social policies antipathetical to extensive security, like the pari passu principle[,] which are less easily refuted". 3

The pari passu principle is said to be "the foremost principle in the law of insolvency around the world". ${ }^{4}$ Commentators claim to have found this principle entrenched in jurisdictions far removed

\footnotetext{
* Lecturer in Laws, University College London. I am grateful to Alison Clarke for her invaluable help, to Dan Prentice for thoughtful criticism and encouragement, and to John Armour, Michael Bridge, Ian Fletcher, Stephen Guest, Look Ho, Tomas Vial, and an annonymous referee for illuminating comments. The views expressed and the mistakes made are mine alone.

1 Venessa Finch, "Security, insolvency and risk" (1999) 62 M.L.R. 633, 634 (footnotes omitted). It is unclear whether Finch is making an all-inclusive claim: that the normal rule is that all creditors, of whatever type, are treated equally. If she is, then the claim is too broad; there is not, nor has there ever been, any such "normal rule". Only those in "relative positions of equality", judged by reference to the general (non-insolvency) law, are covered by the principle: see Oditah, "Assets and the treatment of claims in insolvency" (1992) 108 L.Q.R. 459, 463. This point is taken up again below. See also Goode, "Is the law too favourable to secured creditors?" (1983-4) 8 Canadian Business L.J. 53, 58-59, and Goode, "Proprietary rights and unsecured creditors", in Barry Rider (ed.), The Realm of Company Law (London, Kluwer, 1998), 183, 184

${ }^{2}$ Michael Bridge, "The Quistclose Trust in a world of secured transactions" (1992) 12 O.J.L.S. 333,340 .

3 Ross Cranston, Principles of Banking Law (Oxford, Clarendon, 1997), p. 436.

${ }^{4}$ See the excellent study by Andrew Keay and Peter Walton, "The preferential debts regime in liquidation law: in the public interest?" [1999] C.f.i.L.R. 84, 85.
} 
from ours in geography and time. ${ }^{5}$ In English law, statute itself seems to confirm Finch's "normal rule", that all creditors of an insolvent company are to be treated "equally" by having their preinsolvency claims abated rate and rate alike. ${ }^{6}$ The principle is thought to be "all-pervasive", and its effect is to "strike down all agreements which have as their object or result the unfair preference of a particular creditor by removal from the estate on winding up of an asset that would otherwise have been available for the general body of creditors". 7 The Cork Committee, despite noting significant exceptions to the principle, reiterated its fundamental importance. ${ }^{8}$ The principle is said to be supported both by the need for an orderly liquidation of insolvents' estates, and by requirements of fairness. So it is not surprising that its invocation as the starting point for, say, the debate on the priority of secured or preferential claims, weights the argument in a particular way. Since the pari passu principle has been recognised so widely and for so long as vital, and since it serves such desirable aims as orderliness in liquidation and fairness to all creditors, any deviation from it must be a cause for concern. It seems to follow therefore that: "Before a creditor is entitled to claim a preferred position it must be demonstrated that deviation from the inveterate and equitable pari passu principle is warranted". ${ }^{9}$ On this view, the priority, say, of secured or preferential claims is an abnormality, a pathology to be diagnosed and controlled, perhaps even "cured". Since "equality" is the norm, the onus must be on those supporting differing priorities to justify their claim. To the extent that their efforts are unpersuasive, the case for priority must be considered not established, and the "default principle" of "equality" must prevail. ${ }^{10}$

This paper seeks to overturn this order of things. It is argued here that the pari passu principle is rather less important than it is sometimes made out to be, and does not fulfil any of the functions often attributed to it. It does not constitute an accurate description of how the assets of insolvent companies are in fact distributed. It

${ }^{5}$ See e.g. J. Garrido, "The distributional question in insolvency: comparative aspects" (1995) 4 I.I.R. $25,29$.

${ }^{6}$ Insolvency Act 1986 (hereafter, "IA") s. 107 (voluntary liquidation; however, the section begins: "Subject to the provisions of this Act as to preferential payments ...") and Insolvency Rules 1986, 4.181(1) (compulsory liquidation). The principle can be traced back to the first attempt to deal with insolvency issues by statute; see $34 \& 35$ Hen. 8 c. 4 , s. 2 .

7 Goode, Principle of Corporate Insolvency Law (London, Sweet \& Maxwell, 1997) (2nd ed.) (hereafter, Insolvency), p. 142.

8 Insolvency Law and Practice (Cmnd. 8558, 1982) (hereafter, “Cork Report”), para. 1220.

${ }_{10}$ Keay and Walton, "Preferential debts", p. 92.

${ }^{10}$ Ibid. The Report by the Review Group, A Review of Company Rescue and Business Reconstruction Mechanisms (DTI, May 2000) reiterates the same orthodoxy; see p. 10 para. 24. 
has no role to play in ensuring an orderly winding up of such companies. Nor does it underlie, explain, or justify distinctive features of the formal insolvency regime, notably, its collectivity. The case-law said to support the pari passu principle serves actually to undermine its importance. And the principle has nothing to do with fairness in liquidation. The paper concludes by examining the actual role of the principle. If the arguments made here succeed, then the initial onus of justifying their position shifts from those arguing in favour of the priority of secured and preferential creditors etc., to those who support a more "equal" distribution of the insolvent's estate. ${ }^{11}$

Since there is confusion in the literature about the correct identification of the pari passu principle, it would be useful to begin with a word on terminology. The pari passu principle, as it appears in (corporate) insolvency law, has a fairly specific purpose. It seeks to be informative, to answer the broad question how insolvency law decides on the treatment of different types of creditor. The answer offered by this principle is that insolvency law "takes them exactly as it finds them". ${ }^{12}$ Put differently, creditors holding formally similar claims under non-insolvency law are to be paid back the same proportion of their debt in their debtor's insolvency. ${ }^{13}$ The pari passu principle, then, is one manifestation of formal equality in insolvency law.

However, it is not the only one. As explained in the following Section, insolvency law itself creates exceptions to the pari passu principle, the most notable for our purposes being that in favour of preferential creditors. Some of the claims held by the insolvent's employees, and some tax liabilities owed by the insolvent, rank ahead of general claims, such that all preferential debts must be discharged in full before general unsecured creditors are paid anything. ${ }^{14}$ The factor which causes confusion is that preferential claims also abate rateably as amongst themselves. Some commentators have therefore been led to regard the treatment of preferential creditors inter se as another application of the same pari passu principle. ${ }^{15}$ But this view is unsound in several different

${ }^{11}$ References to "equality" (within quotation marks) are to be read as indicating formal equality, defined for the moment as that understanding of equality espoused by the supporters of the pari passu principle; see e.g. the quotation from Finch which opened this Section. This is to be contrasted with the true equality which results from treating people as equals. This is explained in Section 5, below.

12 Re Smith, Knight \& Co., ex p. Ashbury (1868) L.R. 5 Eq. 223, at 226, per Lord Romilly M.R.

${ }^{13}$ See e.g. Worsley v. Demattos (1758) 1 Burr. 467; 97 E.R. 407, 412, per Lord Mansfield, who identified as one of the purposes of bankruptcy law an "equal distribution among creditors who equally gave a general personal credit to the bankrupt" (emphasis added). So personal creditors but not proprietary ones (both types defined by non-insolvency law) are to rank equally inter se for the purpose of bankruptcy distribution.

${ }^{14}$ IA, s. 175.

${ }^{15}$ For example, Goode, Insolvency, p. 156, states that "preferential debts rank pari passu among themselves". See also Finch, "Is pari passu passé?" [2000] Insolvency Lawyer 194, 194 and 
ways. Most obviously, it ignores the received understanding of the nature of the "equality" principle, that the determination of "equality" is to be made by pre-insolvency law. ${ }^{16}$ Second, it reduces the principle to triviality, since the principle now provides simply that those determined by insolvency law to be equal are to be treated equally by insolvency law. But now pari passu is not a rule or a restriction or a standard. It neither imposes a requirement which insolvency law must fulfil, nor does it shape that law in any way. It is merely a description of what insolvency law actually does, and it fits perfectly with whatever scheme of priorities that law might devise. As a triviality the principle is harmless, but for the same reason it is also uninformative. It no longer says anything about why insolvency law chooses to declare certain creditors to be "equals". Finally though, and confusingly, the commentators who regard the distribution to preferential creditors inter se to be governed by the pari passu principle, still accept that the existence of preferential claims itself constitutes an exception to that principle. ${ }^{17}$ Viewed thus, their position becomes something of a paradox: the treatment of preferred claims is both an exception to, and yet an application of the pari passu rule! Most readers would find it difficult to imagine too many other situations which both exemplify and contradict one and the same principle.

It is suggested that this view of the "equality" principle, which renders the principle both trivial and paradoxical, is unhelpful and should be abandoned. A little care with terminology dissolves the paradox and restores the principle to its roots. A distinction must be drawn between the sort of formal equality represented by pari passu (the equality of creditors as determined by the pre-insolvency form of their claim) and other manifestations of formal equality introduced by insolvency law itself (such as that which holds between some employee- and some Crown-claims, but not between these and claims held by a trade creditor, say). Accordingly, references to pari passu in this paper are to be understood in line with this distinction. To break the monotony of recurrence, "the 'equality' rule (or principle)" will sometimes be employed as synonymous with pari passu. Formal equality other than that enshrined in the pari passu principle will be clearly identified by the context.

199, including fn. 36; the definition of the principle that she embraces in this article seems to be inconsistent with the one quoted at the beginning of this Section.

${ }^{16}$ See the discussion above, and especially Re Smith, Knight \& Co. (1868) L.R. 5 Eq. 223, 226.

${ }^{17}$ See Goode, Insolvency, pp. 152 and 156, and Finch, "Pari passu", pp. 194 and 195. 


\section{The Myth of Pari Passu Distribution}

Despite the hold exercised by the "equality" principle on the imagination of insolvency lawyers, the principle is sometimes acknowledged, as a descriptive matter, not to have too much application in the real world. After proclaiming that the principle is "fundamental and all-pervasive", Goode adds that "This, at least, is the theory of insolvency law". ${ }^{18}$ Fidelis Oditah, who also regards it as "fundamental", explains at the same time that the pari passu norm is "shallow", since it is subject to numerous exceptions, and since it does not in itself acknowledge the "obvious truth" that insolvency law often exempts those holding certain dissimilar preinsolvency rights from having to submit to an "equal" distribution. ${ }^{19}$ The Cork Report noted that rateable distribution among creditors is rarely achieved. ${ }^{20}$ And Keay and Walton state that the "equality" principle is "nothing more, and has little relevance, other than to act as a convenient default principle". ${ }^{21}$

It would be instructive to consider just how extensive these deviations from the "normal rule" really are. Disregard for the moment the priority given to those with a consensual property right. Goode explains that the treatment of secured creditors, suppliers of goods under reservation of title (ROT) clauses, and "creditors for whom the [debtor] company holds assets on trust", all are not to be considered true exceptions to the pari passu principle, since "such assets do not belong to the company and thus do not fall to be distributed among creditors on any basis". ${ }^{22}$ Some five categories of "true exceptions" established by statute can still be identified. ${ }^{23}$

First are rights of insolvency set-off, which are wider in effect than those available outside insolvency. Set-off applies whenever there have been mutual credits, mutual debits or other mutual dealings, before the onset of liquidation, between the debtor and any of its creditors. $^{24}$ The cross-claims need not impeach the debt owed to the insolvent, so long as the requirement of mutuality is satisfied. ${ }^{25}$ "The right of set-off on insolvency represents a major incursion into the pari passu principle", since to the extent that there are mutual credits,

${ }^{18}$ Insolvency, pp. 142-143.

19 "Assets", p. 463.

${ }^{20}$ Para. 1396.

21 "Preferential debts", p. 94. It is suggested below that even this might be over-stating the principle's significance.

22 Insolvency, p. 152. Satisfactory or not, the same reasoning applies to hire-purchase agreements and finance leases.

23 Ibid. Oditah discusses four "important exceptions"; see "Assets", pp. 466-468.

${ }^{24}$ Insolvency Rules 1986, r. 4.90.

25 Peat v. Jones (1881) 8 Q.B.D. 147; Mersey Steel \& Iron Co. v. Naylor, Benzon \& Co. (1882) 9 Q.B.D. 648 , (1884) 9 App. Cas. 434. 
debits or other dealings, the creditor able to assert set-off rights gets a pro tanto priority over others. ${ }^{26}$ What is especially significant given our focus, this priority is mandated by the Legislature, ${ }^{27}$ and operates automatically at the date of the winding-up order without the need for any intervention by either party. ${ }^{28}$ Parties, in other words, are compelled to breach the pari passu principle.

Second, creditors whose claims arise after the winding-up order has been handed down are given a privileged position. Statute provides that their claims are to be treated as part of the expenses of liquidation, are therefore to be given "pre-preferential" status (i.e. ranking ahead of preferential creditors), and are to be paid, not proved. ${ }^{29}$ In additions, utility suppliers "may make it a condition of the giving of the supply that the [liquidator] personally guarantees the payment of any charges in respect of the supply". ${ }^{30}$

A third and related category is constituted by pre-liquidation creditors who can compel payment by virtue of their ability to inflict certain types of harm on the insolvent estate. This category covers payments to avoid forfeiture of a lease, distress or termination of a contract. ${ }^{31}$ In general, creditors whose continued co-operation is desired by the liquidator may be able to extract payments in respect of pre-insolvency debts. ${ }^{32}$

Then there are preferential claims themselves. These include various taxes collected by the debtor on behalf of the Crown, including some PAYE deductions, unpaid VAT, unpaid car tax, general betting, bingo, and gaming licence duties, some pool betting duties, and unpaid social security contributions. ${ }^{33}$ Levies on coal and steel production, beer duty, lottery duty, insurance premium tax, air passenger duty and landfill tax have also been added to this list. ${ }^{34}$ Then there are certain debts related to the insolvent's employees. These include any sums in relation to occupational pension schemes, remuneration of employees up to $£ 800$, accrued holiday pay, and any sums loaned and used for the specific purpose of paying employees' remuneration. ${ }^{35}$

${ }^{26}$ Goode, Insolvency, p. 153.

${ }^{27}$ National Westminster Bank Ltd. v. Halesowen Presswork and Assemblies Ltd. [1972] A.C. 785 (HL); see the discussion in Section 4, below.

28 Stein v. Blake [1996] 1 A.C. 243 (HL); Gye v. McIntyre (1991) 171 C.L.R. 609 (High Court of Australia). The relationship between rights of insolvency set-off and those of secured creditors holding charge-backs is itself a vexed one; for the view that in certain circumstances, set-off should operate despite the existence of a charge-back, see Mokal, "Resolving the MS Fashions 'paradox" " [1999] C.f.i.L.R. 106.

${ }^{29}$ IA, ss. 115 (voluntary winding-up), 156; IR, rr. 12.2 and 4.218.

${ }^{30}$ IA, s. 233(2)(a).

${ }^{31}$ Goode, Insolvency, p. 156.

32 Oditah, "Assets", p. 467, citing Re Levi \& Co. Ltd. [1919] 1 Ch. 416 as an example.

${ }^{33}$ IA, Sch. 6.

${ }^{34}$ Ibid.

${ }^{35}$ Ibid. See generally the useful summary in Keay and Walton, "Preferential debts", pp. 91-92. 
Finally, various types of debt have been deferred by statute. These include debts owed by the insolvent to a director (including shadow director) found liable for wrongful or fraudulent trading, and ordered to be deferred by the court. ${ }^{36}$ Claims held by the debtor's shareholders or other members qua members also fall under this head. ${ }^{37}$

So the claims of creditors able to assert set-off, utility companies, post-liquidation creditors, pre-liquidation creditors with post-insolvency leverage, nineteen different types of preferential claims, and claims of deferred creditors, all fall outside the purview of the pari passu principle. And even these "deviations" from the "normal rule", while patently substantial, might in fact be "something of a minor qualification" to the "equality" norm. ${ }^{38}$ There are numerous other types of creditor not affected by it. Under certain circumstances, this includes claims held by accountants, solicitors, stockbrokers, factors and bankers, all of whom might be able to benefit from common law liens which arise by operation of law. ${ }^{39}$ Statute gives the unpaid seller a lien on the goods sold, and rights of stoppage in transit. ${ }^{40}$ If the insolvent was insured, a party injured by its actions (a tort creditor) is subrogated to its rights against the insurer. ${ }^{41}$ If the liability in question arose under circumstances governed by the Road Traffic Act 1988, the insurer might be liable to the tort creditor even in those circumstances where it would have been able to avoid or cancel the policy as against the insured. ${ }^{42}$ This of course continues to disregard those able to assert consensual property rights in some assets ostensibly within the insolvent's estate.

Consider these principles in the light of recent data on the sources of external funding for small to medium sized enterprises (SMEs), ${ }^{43}$ which provide insolvency law with most of its business. ${ }^{44}$ In a survey covering the period 1995-1997, 47\% of this was found to have been provided by banks (who often take security), $27 \%$ by hire purchase/leasing firms (proprietary rights), $6 \%$ by partners and shareholders (may or may not be deferred by statute), $6 \%$ by factoring businesses (liens and consensual proprietary rights), 4\%

${ }^{36}$ IA, s. 213 (fraudulent trading), 214 (wrongful trading), s. 215(4).

37 IA, s. 74(2)(f).

38 Oditah, "Assets", p. 467.

39 Ibid., p. 469 fn. 67, citing Snell's Equity (29th ed.), Chap. 10.

40 Sale of Goods Act 1979, ss. 39 and 41-46.

41 Third Parties (Rights Against Insurers) Act 1930, s. 1(1).

${ }^{42}$ See s. 151(5).

${ }^{43}$ Finch provides a useful summary; see "Security", p. 636, and the sources she cites in fn. 18.

44 The Association of Business Recovery Professionals (or ABRP; formerly, SPI), Survey of Business Recovery in the UK: 9th Survey (2001, available at URL: WWW.SPI.ORG.UK/9thc/), p. 7, shows that in the year to June $1999,88.5 \%$ of companies which became subject to a formal insolvency proceeding had a turnover less than $£ 5 \mathrm{~m}$. 
by other individuals, $4 \%$ by other sources, $3 \%$ by venture capitalists (equity claimants, hence ranking below debtors), and $1 \%$ by trade customers (who have the option of setting up Kayford trusts ${ }^{45}$ ). Also important, especially for small businesses, is trade credit. By some estimates, stocks and flows of trade credit are twice the size of bank credit. ${ }^{46}$ At least some (perhaps much) of the credit in this category also generally falls beyond the application of the "equality" norm. One survey (which, because of its age, probably underestimates the extent to which ROT's are employed) found that well over half the suppliers surveyed (59\%) used ROT clauses. ${ }^{47}$ This figure seems to rise dramatically, the more troubled the debtor in question. ${ }^{48}$

These are of course the sources from which firms raise capital while they are solvent. These figures do not directly indicate the composition of the overall debt of firms which are in financial distress, or which are undergoing some formal insolvency procedure. Intuitively, however, it would be surprising if the debt outstanding when a firm became distressed generally had a structure very different from the one mentioned above. And in fact there is some fresh data which confirms this intuition. Julian Franks and Oren Sussman have recently compiled a data set of more than 500 firms which had bank debt, and which were in financial distress. ${ }^{49}$ This confirms that the structure of debt of the firms in the "rescue units" of the three banks studied is very similar to that for solvent firms as a whole..$^{50}$

Even more significant is the fact that, in an overwhelming majority of formal insolvency proceedings, nothing is distributed to general unsecured creditors (the only category of claimant truly subject to the pari passu rule). It is estimated that there are zero returns to them in $88 \%$ of administrative receiverships, $75 \%$ of

45 In re Kayford (in liq.) [1975] 1 W.L.R. 279; for a critical discussion, see Goodhart and Jones, "The infiltration of equitable doctrine into English commercial law" (1980) 43 M.L.R. 489. The Re Kayford method seems to have been upheld by the Court of Appeal in Re Chelsea Cloisters Ltd. (1981) 41 P.\&C.R. 98, but that case is criticised as "an exercise in discretionary justice" by Bridge, "Quistclose", pp. 356-357.

46 Bank of England, Finance for Small Firms: A Seventh Report (January 2000), p. 26 fn. 17, referring to Singleton and Wilson, Sources and Use of External Finance: An Empirical Study of UK Small Firms.

47 J. Spencer, "The commercial realities of reservation of title clauses" [1989] J.B.L. 220, 221.

${ }^{48}$ S. Wheeler, Reservation of Title Clauses (Oxford, OUP, 1991), p. 5, found that in the fifteen receiverships and liquidations studied, $92 \%$ of suppliers had employed some sort of ROT provision.

49 The Cycle of Corporate Distress, Rescue and Dissolution: A Study of Small and Medium Size UK Companies, Institute of Finance and Accounting (London Business School) Working Paper 306-2000, April 2000 (published on 2.11.00).

${ }^{50}$ For the three banks respectively, the mean debt owed to the types of creditor indicated as a percentage of total outstanding debt, was as follows: Main Bank $38.2 \%, 49 \%, 41.9 \%$; Trade Creditors $24 \%, 37.4 \%, 40.2 \%$; Other Financial Institution $2.3 \%, 2.8 \%, 7.5 \%$; Other Creditors $29.4 \%, 8.3 \%, 8 \%$; "Owner"-Directors $6.1 \%, 2.5 \%, 2.4 \%$; see ibid., p. 8, Table 3. More on this in the penultimate Section of this paper. 
creditors' voluntary liquidations, and $78 \%$ of compulsory liquidations. On average, they receive $7 \%$ of what they are owed. ${ }^{51}$

So while the matter is an empirical one, and while the position would of course vary from debtor to insolvent debtor, the discussion so far and these statistics show that most types of claim either are or can be exempted from the application of the pari passu principle. It is also likely that in most if not all liquidations, hardly any claimant is paid pari passu. Given these reasonable deductions, one might perhaps be forgiven for questioning whether it is fair to describe the pari passu principle as "the normal rule in a corporate insolvency". ${ }^{52}$ In fact, it is the differing priorities of claims which seem to represent the rule. What seems certain is that, in the distribution of the assets of insolvent estates, "equality" between different types of claim must be very much the exception. Put differently, even if unsecured claims other than preferential claims form the bulk of the claims in most liquidations, most of the available assets would not be distributed "equally". The pari passu rule is supposed to govern distributions. It should be obvious, however, that distribution in accordance with this rule is virtually non-existent. ${ }^{53}$

Some readers would object that the discussion so far does little more than state the obvious, since everyone knows the current law leaves little room for anything to be distributed pari passu in an overwhelming proportion of insolvencies. These readers dramatically underestimate the extent to which insolvency scholarship still clings to the pari passu myth. Leading insolvency scholars (and courts) regularly assert that this jurisdiction has a "pari passu insolvency regime", that the "equality" rule has been varied "only slightly ... in respect of personal claimants", that the "present law ... is disinclined to force particular classes of creditors to shoulder greater burdens" than others by causing derogations from the "equality" principle in favour of the latter (or against the former). ${ }^{54}$ With respect, such assertions very misleadingly push the pari passu principle to the fore as currently the dominant method for the distribution of insolvent estates. They are then used as premises in further analysis which in turn is often (not always) distorted as a result. That is to be

${ }^{51}$ ABRP, Survey, p. 18. This is supported by the Franks-Sussman data, which shows that the median recovery rate for unsecured creditors in a sample of 27 administrative receiverships is $0 \%$; see Cycle, p. 14, Table 9, n. 1.

52 To this author, "normal" indicates a state of affairs which is usual, regular, common, average, or typical.

53 The implications of this distinction between the constitution of claims and the pattern of distribution is discussed further in Section 6 of this paper.

54 These quotations are from Finch and Worthington, "The pari passu principle and ranking of restitutionary rights", in Rose (ed.), Restitution and Insolvency (Mansfield, Oxford, 2000), 1, pp. 14-15, 2 and 7, including fn. 33 (emphases added). 
regretted. Much of science could not progress till it had rejected the false geocentric picture of the cosmos. In its rather more modest sphere, insolvency scholarship must somehow tear itself away from the equally false view that the "equality" principle occupies the centre of the insolvency law universe.

Still, let us take seriously the objection noted above. Perhaps the discussion so far has missed the point. The claim that priority is a pathology might not be a descriptive one after all. Those making it might, on reflection, be willing to concede that the pari passu principle reflects little of reality, which (they might come to accept) consists of widely divergent priorities accorded to different types of claim. The critics of differential priority might now argue the "equality" norm constitutes the ideal against which our existing insolvency law must be judged, since it enshrines desirable goals that any reasonable insolvency regime must attain. Deviations from pari passu are to be condemned for making the attainment of those goals more unlikely, and they are to be condemned even more precisely because they are so widespread. It is to this claim that we now turn.

\section{The Immunity/Priority Fallacy}

For English lawyers, it seems the primary attraction of the pari passu principle is its ability to provide for an orderly liquidation. Goode makes the point firmly:

It is this principle of rateable distribution which marks off the rights of creditors in a winding up from their pre-liquidation entitlements. Prior to winding up each creditor is free to pursue whatever enforcement measures are open to him ... The rule here, in the absence of an insolvency proceeding, is that the race goes to the swiftest ... Liquidation puts an end to the race. The principle first come first served gives way to that of orderly realisation of assets by the liquidator for the benefit of all unsecured creditors and distribution of the net proceeds pari passu. ${ }^{55}$

Keay and Walton see the principle as the embodiment of similar virtues:

the whole idea of pari passu distribution is to ensure parity of benefit, no matter what resources one has-if there were no pari passu distribution we would return to the "first come, first served" policy of mediaeval times, which saw those with the greatest resources and power taking the debtor's estate. ${ }^{56}$

55 Insolvency, p. 142.

${ }^{56}$ Keay and Walton, "Preferential debts", p. 95; see also pp. 92-93. Bridge also regards the "equality" principle as reflecting the law's interest in an orderly liquidation; see "Quistclose", p. 340, though he strikes a note of scepticism on the same page: just how "fundamental" could the principle be "when one [must] look ... for it in the Insolvency Rules and not in the body of the [Insolvency] Act itself[?]" (footnote omitted). 
And for Finch, the "equality" principle "conduces to an orderly, collective means of dealing with unsecured creditor claims and ... involves lower distributional costs than alternative processes such as "first come, first served" ".57 For these commentators, the choice is clearly between a free-for-all where weak creditors would inevitably be beaten into last place by better-resourced competitors, and where the advantages associated with an orderly liquidation would be lost, and the pari passu principle which alone stands as a bulwark against this.

What is more, and even given its less than universal efficacy, the pari passu principle, it is said, "retains some practical importance, if only in a negative sense, in that it may have the effect of invalidating pre-liquidation transactions by which a creditor hopes to secure an advantage over his competitors". ${ }^{58}$ The principle is widely seen to be "very much at the heart of the rationale for the avoidance of pre-liquidation transactions". ${ }^{59}$ Oditah notes that "In one sense, avoiding powers provide illustrations of insolvency law's commitment to the principle of equality". ${ }^{60}$ And Goode observes that "the principle of equity among creditors which underlies the pari passu rule of insolvency law will in certain conditions require the adjustment of concluded transactions which but for the winding-up of the company would have remained binding on the company". ${ }^{61}$

Given that the pari passu principle lies at the very heart of the orderly liquidation regime, and given its role in justifying some of the most distinctive and well-established aspects of insolvency law (its preference and other avoidance provisions), any deviations from it must naturally be considered odious at least prima facie. "Equality" of treatment serves key practical and justificatory purposes which bring social benefits; so differential priority, its opposite, must result in a diminution of all those benefits. Those defending the priority, say, of secured claims must therefore bear a heavy burden of proof.

It is submitted that these arguments are based on a misunderstanding of the nature of the liquidation regime. All these

57 Finch, "Pari passu", p. 194, noting a "traditional justification" for the principle. See also Finch and Worthington, "Pari passu", pp. 2-3.

58 Insolvency, p. 144.

59 Keay and Walton, "Preferential debts", p. 93, fn. 74, citing Keay, Avoidance Provisions in Insolvency Law (Sydney, LBC Information Services, 1997), 40-49.

60 "Assets", p. 465.

61 Insolvency, p. 344; see also pp. 345-348, where the link between the avoidance provisions of the Insolvency Act and insolvency law's "equality" principle is reiterated, pp. 387, 389-390 (preferences), and p. 423, which explains the rule against post-petition dispositions by invoking the principle. Goode does point out, however, that the principle cannot explain certain important nuances of some of these provisions; see especially p. 347; for a dramatic modification of the claim quoted in the text and the references above, see p. 441 . 
arguments commit what will be referred to as the immunity/priority fallacy. Once that fallacy is exposed and exploded, the rationales given by those supporting the pari passu principle will be seen to provide no justification for it. And that principle in turn is shown not to play any role in bolstering the desirable properties of the liquidation regime.

Let us start by understanding the distinction between priority and immunity. $^{62}$ Recall again the old image, that of the debtor firm's estate forming a pool of assets. As the firm approaches the stage where its assets are insufficient to meet its liabilities, ${ }^{63}$ and in the absence of a special liquidation regime, the firm's creditors have an incentive to rush to enforce their claims. The earlier they can get a judgment and execute it, the more likely it is they would get paid in full, or at all. The tardy creditor would find that nothing is left for him, the pool already having been drained of all its contents. Further, and on the eve of insolvency, creditors aware of the firm's troubles and able to influence its decisions might try to steal the first drink from the asset pool by getting the debtor to repay them. Their gain is a collective loss. The "first come, first served" system encourages creditors to engage in duplicative (hence wasteful) monitoring of their debtor in order not to be left behind in any race to the pool. It adds uncertainty and therefore decreases the utility of risk-averse creditors. And for the debtor whose assets are more valuable if disposed of together as a going concern, the individualistic system increases the possibility that those assets would be broken up nonetheless and sold piecemeal to satisfy claims as they arise. ${ }^{64}$ It is this value-destroying activity that the dedicated liquidation regime must prevent. Notice the cause of all the trouble: each creditor faces the necessity, and has the ability, to act individually, in disregard of the interests of all others. Hence the obvious solution: the dedicated liquidation regime is collective, decisions being taken on behalf of all those interested in the asset pool.

The analogy and the insight can be taken further. The individualistic pre-insolvency debt-collection regime is a mad race to the asset pool. Since that race is undesirable, the collective insolvency system steps in to stop it. The creditors are now forced

${ }^{62}$ See Mokal, "The Authentic Consent Model: Contractarianism, Creditors' Bargain, and Corporate Liquidation" [2001] Legal Studies 400, 438: "[P]arties in the choice position accept a distinction that will be referred to as that between immunity and priority". For the ancestry of this distinction, see Douglas Baird and Thomas Jackson, Cases, Problems, and Materials on Security Interests in Personal Property (Mineola, NY, Foundation Press, 1987), 67 (discussing the "property right" and the "priority right" of secured creditors).

${ }^{63}$ IA, s. 123.

${ }^{64}$ See e.g. Thomas Jackson, "Bankruptcy, nonbankruptcy entitlements, and the creditors' bargain" (1982) 91 Yale L.J. 857, and Mokal, "Authentic Consent". 
to queue up to have access to the pool. Voidable preferences and post-petition dispositions of assets etc. can now be seen as attempts by some creditors to bypass this queue. In other words, they represent efforts to gain immunity from the collective system. Insolvency law deploys various mechanisms to deny them this immunity. ${ }^{65}$ So long as there is no race to the pool, no one succeeds in stealing a drink from it, and creditors await their turn to have access to the debtor's resources, decisions can be made systematically and in the common interest. Crucially, though, note that ensuring that creditors take their place in the queue is one thing. The order in which they line up is, in general, quite another. Each creditor's priority is their place in the queue relative to each other creditor. But espousing the aim that creditors all line up does not entail any particular order in which they should line up. It does not commit the system to placing all creditors (as it were) unidistant from the asset pool. The pari passu principle would put each ("similar") creditor side by side rather than, say, one after the other. But this arrangement is not a necessary concomitant to the absence of the value-destroying race. So long as there is a queue (with creditors standing side by side, one after the other, or in whatever order), there is no race.

Consider now the various comments noted at the beginning of this Section. It can be seen that they represent the immunity/ priority fallacy. This can be defined as attribution of the benefits resulting from the absence of immunity from a collective insolvency system, to an imaginary and irrelevant state of equal priority (the realm of pari passu). If the pre-insolvency "first come, first served" system is objectionable in a firm's insolvency, it is so because of the monitoring, uncertainty, administrative, and loss of synergetic value costs described above. All these costs result from an individualistic regime, and all of them are avoided by a collective one. As long as all those creditors whose actions would inflict those costs participate in the collective regime or submit to collective decision-making, how their claims are ranked relative to each other within the collective scheme of distribution is (for these purposes) irrelevant. ${ }^{66}$

${ }^{65}$ For example, IA, ss. 239 (preferences) and 127 (post-petition dispositions).

66 The reader would have noted the italicised qualification as significant. Without entering into the debate about its justifiability here, it should be pointed out that secured creditors, for example, acquire both priority and immunity in their debtor's insolvency. See Re David Lloyd \& Co. (1877) 6 Ch.D. 339, 344-345, per James L.J.: "[The insolvency rules which deprive unsecured creditors of the ability individually to proceed against their debtor] were intended, not for the purpose of harassing, or impeding, or injuring third persons, but for the purpose of preserving the limited assets of the company ... in the best way for distribution among all persons who have claims upon them ... But that has really nothing to do with the case of the man who for present purposes is to be considered as entirely outside the company, who is merely seeking to enforce a claim, not against the company, but to his own property ... Why a mortgagee should be prevented from doing that I cannot understand". 
Similarly, if certain attempts to gain preference are undesirable, that is because they undermine the benefits associated with collective decision-making. Consider the following situation. In the liquidation of a particular company, there is only one general unsecured creditor (say a trade creditor without the benefit of an effective ROT clause) and one preferential creditor (the Crown). Suppose the former engineers a (voidable) preference in his favour, so that both he and the preferential creditor finally get back the same proportion of their debts. ${ }^{67}$ Now the situation here simply cannot be objectionable on the basis that the pari passu rule has been breached. In fact, the outcome would probably be perfectly in accord with this rule, since the general creditor is likely to hold the same sort of non-insolvency claim as the preferential one. So if the rule applies, he should get back the same proportion of his debt as the latter. However, the voidable preference provisions have been violated nevertheless. So the pari passu principle does not underlie these provisions, at least as they apply here. If this much is accepted, then the argument can be pressed further. It would not help to suggest that the principle justifies the preference avoidance provisions as they apply to a trade creditor who has been paid a greater proportion of his debt than another, say, but not when they apply to a trade creditor and an employee who both get the same proportion of what they are owed. To advocate this position would again be to create something of a paradox: that the need to provide "equal" treatment legitimates the avoidance of a preference in the first situation, but actually providing such treatment constitutes the objectionable preference in the latter!

In fact, to understand the basis of the preference avoidance provisions, we must switch to the perspective suggested above. The party given the voidable preference has been allowed to leave the place assigned to him by the insolvency system. He has been allowed to skip the queue for the insolvent's assets. This is the factor which creates the preference. ${ }^{68}$ This example should make it clear pari passu is not simply irrelevant to understanding the preference (and several other) avoidance provisions. In fact, the

\footnotetext{
${ }^{67}$ This contravenes the rule that general unsecured creditors are to be paid nothing until all preferential debts have been fully honoured; see IA, s. 175.

68 David Milman and Rebecca Parry "Challenging transactional integrity on insolvency: An evaluation of the new law" (1997) 48 Northern Ireland L.Q. 24, 25-26, perhaps come closest to the view expressed here. See also Worsley v. Demattos (1758) 1 Burr. 467; 97 E.R. 407, 412, per Lord Mansfield, who seems to regard as distinct two types of violation of bankruptcy law which result from a voidable preference. The creditor accorded such a preference gains immunity from the management decisions taken in the collective interests of all creditors by the trustee, and in addition, escapes having to participate in the rateable distribution of the estate.
} 
focus on the "equality" principle can be positively misleading in this regard. ${ }^{69}$

\section{The Pari Passu Principle in Action?}

It is to be noted that the argument here is not one for a change in the law, for example to abolish the pari passu rule. The point is rather that the alleged manifestations of the principle are nothing of the sort. The law as it stands today is better understood by adopting the analysis in the previous Section. That the veneration of the pari passu principle is false becomes clear when one examines the case-law said to support it. It must be emphasised that the only purpose of discussing these decisions is to show that reliance on them in support of the pari passu principle is misguided. It should be noted also that the order in which these cases are discussed is thematic, not historical.

Goode seems to cite Ex parte Mackay ${ }^{70}$ as authority for the proposition that "The pari passu rule may not be excluded by contract". ${ }^{71}$ In this case, A and B entered into an agreement for A to sell a patent to $\mathrm{B}$. B promised in return to pay over to $\mathrm{A}$ the royalties received, and, in addition, lent $\mathrm{A} £ 12,500$. It was also agreed that, for satisfaction of this debt, B would have a lien over one-half of the royalties received, except if $\mathrm{A}$ became bankrupt, in which case $\mathrm{B}$ might retain all the royalties. A became bankrupt. It was held on appeal that the provision allowing for B to have additional security in the event of A's bankruptcy was void as being a fraud on the bankruptcy laws. ${ }^{72}$ Goode quotes the following parts of the judgment in support of the inexcludibility of the pari passu rule:

... a man is not allowed, by stipulation with a creditor, to provide for a different distribution of his effects in the event of bankruptcy from that which the law provides. ${ }^{73}$

${ }^{69}$ For the "policy of section 127" of IA, which provides for the avoidance of post-petition dispositions of assets, see Lightman J. in Coutts \& Co. v. Stock [2000] 1 W.L.R. 906, 909 (and approved by the Court of Appeal in Hollicourt (Contracts) Ltd. v. Bank of Ireland [2001] Ch. 555, 563): the provision is "part of the statutory scheme designed to prevent the directors of a company, when liquidation is imminent, from disposing of the company's assets to the prejudice of its creditors and to preserve those assets for the benefit of the general body of creditors". Again, the focus is clearly on the preservation of the insolvent's estate with a view to its eventual distribution under the statutory scheme of distribution; needless to say, whether that distribution should be "equal" or otherwise simply is not implicated in the policy of this section.

70 (1873) 8 Ch. App. 643.

${ }^{71}$ Insolvency, p. 144. Goode's position is not unambiguous, since his argument on this point is rather brief, and is heavily qualified later on in the text. See also Oditah, "Assets", p. 464 and the text accompanying fn. 37, who uses ex p. Mackay to similar effect.

${ }^{72}$ See 8 Ch. App. 643, 648, per Mellish L.J.

73 James L.J. at p. 647 (emphasis added) (the same judge whose dictum concerning secured creditors was reproduced above). 
... a person cannot make it a part of his contract that, in the event of his bankruptcy, he is then to get some additional advantage which prevents the property being distributed under the bankruptcy laws. ${ }^{74}$

But neither of these dicta (nor any other portion of the judgments) make any reference to the pari passu principle. What they do indicate is, simply, that the bankrupt's property is not to be distributed except under the rules of the bankruptcy system. Crucially, a creditor cannot, even ex ante, "get some additional advantage" in any way not itself allowed by that system. To resort to the analogy introduced above, he may not skip his assigned place in the queue, whatever that place might be. The decision provides absolutely no support for the very different proposition that under the liquidation system, the places assigned to creditors are all unidistant from the asset pool. ${ }^{75}$ Quite the reverse is in fact true. We must remember that pari passu was almost as rare in practice at the time of this judgment as it is now. The decision must be seen against the background of a system which (for example) gave extensive preferences to the Crown, including those provided by s. 32 of the Bankruptcy Act 1869. The Crown also had statutory liens over various types of property by virtue of the different Excise Acts. And the Bankruptcy Act 1869, s. 32, had enhanced the pre-existing preference for certain debts owed to the bankrupt's servants and clerks. ${ }^{76}$ In addition, the Bankruptcy Act 1969 , s. 39, provided for mandatory set-off in bankruptcy in the appropriate circumstances. ${ }^{77}$

It should be clear distribution according to the bankruptcy laws was not distribution pari passu. The bankruptcy laws did not place all creditors side by side. The "equality" principle was part of that

\footnotetext{
${ }_{75}^{74}$ Mellish L.J., at p. 648 (emphasis added).

75 That is the proposition it would have to endorse if it were supporting the "equality" principle. See also the only authority referred to in the judgment, Higinbotham v. Holme (1812) 19 Ves.Jun. 88; 34 E.R. 451, which was directly applied by Mellish L.J. (at 647-648). Here, a marriage settlement provided that in case the husband, having previously been educated for orders, should enter into trade and become bankrupt, his life interest would determine. The husband later entered into trade as a cotton manufacturer, and eventually became bankrupt. Lord Eldon L.C. struck down the relevant clauses of the marriage settlement as a fraud on the bankrupt laws (p. 453). There can be no doubt that "equality" of distribution simply was not at issue. The only objection was clearly to the attempt to evade the disposal of the bankrupt's property by way of collective proceedings for his creditors' benefit (pp. 452-453). Thanks to John Armour for emphasising to the author the relevance of this decision.

${ }^{76}$ See Keay and Walton's summary of the history of "Preferential debts", pp. 86-91.

${ }^{77}$ See Ex p. Barnett, In re Deveze (1874) 9 Ch.App. 293, 295-296, per Lord Selborne L.C. Interestingly, the other judges in this case, both of whom concurred in the Lord Chancellor's decision, were Mellish and James L.JJ., the judges who decided Ex p. Mackay. Being aware of this deviation from pari passu provided by the Bankruptcy Act 1869 (as undoubtedly of the others already mentioned), they could not possibly be taken to be laying down or upholding some overriding or general rule in favour of "equal" distribution in Ex p. Mackay (especially since any such rule gets not a single mention in either judgment). On insolvency set-off, see the discussion in the text, below.
} 
regime, but it was by no means the only part (it might not even have been the most important one). In addition, of course, on the facts of this case, the priority provided to B by way of the lien over one-half of the royalties was upheld as perfectly proper by the same judgment. ${ }^{78}$ So, to cite ex parte Mackay as an authority supporting only equal distribution is, with respect, quite wrong, since it is at least as much an authority for the prior inexcludibility of unequal treatment of claims, also provided for by the same laws. The only proposition this decision can be said to support is that one may not bargain for immunity from the collective bankruptcy regime (except as provided by the law). ${ }^{79}$

The sceptical reader should turn to National Westminster Bank Ltd. v. Halesowen Presswork and Assemblies Ltd. ${ }^{80}$ The House of Lords held (by a majority of three to one) that since the regime for the administration of insolvent estates embodies important elements of public policy, and since the rights of insolvency set-off form part of that regime, the creditor given such set-off rights cannot contract out of them. This despite the fact that the agreement which precluded insolvency set-off, and which was struck down by their Lordships, seemed specifically to have been concluded (inter alia) to ensure that "certain large payments which were due to the [nowinsolvent] company should be available for distribution pro rata amongst its creditors". ${ }^{81}$ The liquidator's view - that the party now asserting set-off should be "in no better position than any other creditor" in the debtor company's insolvency-was noted, ${ }^{82}$ but rejected.

So an exception to the "equality" principle - the contractual disapplication of which might have led to a more "equal" distribution - is as mandatory as any other part of the liquidation regime. What cannot be contracted out of (in an unacceptable way) is not the pari passu principle, but the whole collective system for the winding-up of insolvent estates. Not only is it forbidden for a creditor to leave his assigned place in the queue and step ahead of others, he cannot even leave his place ahead of others and stand in line with them. The inequality inherent in the system (in this case

${ }^{78}$ See e.g. James L.J., at p. 647.

79 An identical analysis applies to Ex p. Williams (1877) 7 Ch.D. 138 and Ex p. Jackson (1880) 14 Ch.D. 725. In both cases, the mortgagee's right to distrain on the chattels upon the mortgaged property was a clear attempt to grant him immunity from the collective bankruptcy proceedings to which the mortgagors were subject, to the extent of the value of the chattels distrained upon. See also the similar case of Re Johns [1928] Ch. 737. All three cases are used by Oditah, "Assets", p. 464, fn. 37, as demonstrating the operation of the pari passu principle. For reasons discussed in the text to which this note is attached, it is submitted that they deal with an entirely different point, with immunity, not priority.

${ }^{80}$ [1972] A.C. 785 (HL).

${ }^{81}$ See the submission on behalf of the company, ibid., p. 792A.

82 Expressly so by at least one of their Lordships; see per Viscount Dilhorne, p. $801 \mathrm{E}$. 
by way of insolvency set-off) is every bit as binding as the equality. Note again that the focus is on attempts to frustrate (some of) the rules of the liquidation regime. Whether that would lead to an increase or decrease in the "equality" of distribution is simply irrelevant. $^{83}$

Let us consider British International Air Lines Ltd. v. Compagnie Nationale Air France. ${ }^{84}$ British Eagle (BE) was a member of a clearing house scheme operated by the International Air Transport Association (IATA). Sums due from participating airlines to each other were netted off at the end of every month. Those with a net credit balance would then receive a payment from the clearing house, while those with a net debit balance were required to pay into the system. BE having gone into liquidation, it was found that it owed money to several airlines, but had a claim against Air France (AF). A bare majority of their Lordships allowed the liquidator to recover that sum on the basis that the netting arrangements contravened the pari passu principle. The Lords rejected AF's contention that the liquidator's only claim lay against the clearing house, and that it could only be for the amount (if any) which remained to BE's credit after the netting-off. According to the majority, the netting arrangements captured for the benefit of the members of the clearing house an asset (the claim against AF) which, but for those arrangements, would have been available for distribution among BE's general creditors.

That this case has been described as "[undoubtedly the] leading modern authority on the pre-eminence of the pari passu principle" 85 is not without irony. The case could not provide any support for the pari passu principle. Recall that this principle supposedly requires "equals" to be treated equally. ${ }^{86}$ And the determination of "equality" is generally left to non-insolvency law:

The Act of Parliament unquestionably says that everybody shall be paid pari passu, but that means everybody after the winding up has commenced. It does not mean that the Court shall look into past transactions, and equalise all the creditors ... It takes them exactly as it finds them. ${ }^{87}$

${ }^{83}$ To similar effect, see e.g. Ex p. Barnett, In re Deveze (1874) 9 Ch.App. 293.

84 [1975] 1 W.L.R. 758 (HL). For criticism of the decision, see the Cork Report, paras. 13411342 .

85 Oditah, "Assets", p. 465; it must be emphasised that Oditah himself is unimpressed by the decision and subjects it to cogent criticism; see p. 466.

${ }^{86}$ The rule that all those who correctly answer $x$ number of questions in an exam are to get $x$ marks, enshrines one type of equality. The rule that all those who take the exam are to get $x$ marks represents quite another. The pari passu principle is traditionally conceived as analogous to the former rather than the latter rule.

87 Re Smith, Knight \& Co., ex p. Ashbury (1868) L.R. 5 Eq. 223, 226, per Lord Romilly M.R. See also Oditah, "Assets", pp. 463 and 468. 
But even Lord Cross, speaking for the majority, accepted that AF, and other members of the clearing house, were never equal to BE's general creditors outside liquidation. ${ }^{88}$ During BE's solvency, the members of IATA could not (unlike BE's non-IATA creditors) just have ignored the clearing house arrangements and sued BE for any sums owed. Correspondingly, BE could not, while solvent, have proceeded directly against AF. It could only have claimed against the clearing house for any net balance due to it. ${ }^{89}$ And yet BE's liquidator was allowed to do precisely what BE would not have been able to do. By the same stroke, BE's IATA creditors were forced to claim directly against BE (by proving in its liquidation) while they would have been neither required nor even allowed to do so before the commencement of its winding-up. Pre-insolvency unequals were forcibly "equalised" in insolvency. This hardly constitutes a vindication of the pari passu principle, no matter what the judicial rhetoric. And in any case, the sums recovered as a result of this decision would not have been distributed pari passu. Pre-preferential and preferential creditors etc. would have taken the first bite. ${ }^{90}$

Perhaps a better way of understanding the disputed issues in British Eagle would be to look at the netting arrangements simply as an attempt on part of IATA to prevent its members from having to submit to the collective liquidation regime. Or at least this is how they seem to have been viewed by the majority of their Lordships. ${ }^{91}$ That such contracting-out (i.e. immunity) was not objectionable per se was also accepted. Lord Cross implied that, had the IATA arrangements created charges in favour of the IATA creditors with effects equivalent to the disputed netting scheme, those would have been effective against the liquidator if duly

${ }^{88}$ [1975] 1 W.L.R. 758, 777C-H; to the same effect, see Lord Morris (dissenting), pp. 764F, 765A and 765E; and Lord Simon (dissenting), p. 771F-H.

89 Ibid., p. 777C-D (per Lord Cross).

90 This point is impliedly noted ibid., at pp. 761B (Lord Morris) and 778H (Lord Cross). Needless to say, had there been a floating charge over the relevant assets, its holder would have been repaid in preference to general unsecured creditors. The same point again seems to have been missed by the Court of Appeal in In re Celtic Extraction Ltd. (in liq.) [2001] Ch. 475, 491, where Morrit L.J. (delivering the Court's judgment), invoked, inter alia, "the very considerable ... public policy requirement that the property of insolvents should be divided equally amongst their unsecured creditors", to uphold the official receiver's ability to disclaim a waste disposal licence as onerous property. The Court's assertion, that any assets preserved by the disclaimer would be distributed pari passu amongst general creditors, is of course without foundation. Any such assets (on the facts, there were none) would mostly go to any floating charge holder and to pre-preferential and preferential creditors.

91 Ibid., p. 780G-H: "[What Air France] are saying here is that the parties to the "clearing house' arrangements by agreeing that simple contract duties are to be satisfied in a particular way have succeeded in 'contracting out' of the provisions contained in section 302 for the payment of unsecured debts 'pari passu'." Note the unnecessary (and inaccurate) emphasis on "equality" at the end of this quotation: what would have been contracted out of was the whole collective regime, its inequality (e.g. in favour of pre-preferential and preferential creditors) as well as its "equality". 
registered. ${ }^{92}$ So the objection was not to the granting of immunity to only some of BE's creditors (or indeed to granting them priority over others). Rather, the majority were of the view that the advantages associated with recognising this novel way of acquiring immunity were not sufficient to outweigh (what they saw as) the costs of such a significant derogation from the collective regime. ${ }^{93}$ This conceptualisation of the majority's decision then also allows one to make sense of the strong dissenting speech by Lord Morris, who emphasised the benefits which flowed from having the netting arrangements. ${ }^{94}$ On the arguments made here, the thrust of the dissenting speeches would of course have to be that these benefits (of allowing the arrangements to prevail) would outweigh any associated costs.

Unfortunately, though, there seems to have been no suggestion in the arguments that the issue should be regarded thus, as a question of balancing the commercial advantages of recognising this novel way of gaining immunity from the liquidation regime against any lessening of the advantages associated with having a collective system. As already mentioned, the latter include the ability to preserve the going concern surplus if there is one, and the minimisation of uncertainty, monitoring and administrative costs. The IATA netting system should have been upheld if the costs to the actors resulting from any increases in uncertainty, monitoring and administrative costs, in the risk that a going concern surplus would be lost, and in the diminution of the pool of assets entailed by the existence of immunity for IATA creditors, were outweighed by the benefits it brought to the same actors. ${ }^{95}$ (Note that this is a

92 Ibid., p. 780C. The existence of such charges would of course accord priority over BE's general creditors to IATA creditors, as well as granting the latter immunity from the collective liquidation regime.

93 Ibid., pp. 780H-781A: "[It] is to my mind irrelevant that the parties to the 'clearing house' arrangements had good business reasons for entering into them and did not direct their minds to the question how the arrangements might be affected by the insolvency of one or more of the parties. Such a 'contracting out' must ... be contrary to public policy. The question is, in essence, whether what was called ... the 'mini liquidation' flowing from the clearing house arrangements is to yield to or prevail over the general liquidation. I cannot doubt that on principle the rules of the general liquidation should prevail". Despite appearances, the objection to granting immunity from the collective regime was not an absolute one. As already noted, the judge had implied earlier in the same paragraph that he would have been content to allow immunity for the IATA creditors by way of security. This also shows the objection was not one of principle. There was no principle involved which laid down, say, that no one can bargain for immunity. The matter was rather of policy. One could only bargain for immunity in an acceptable way (the authority for this is British Eagle itself), and for the right reasons. Even if the method of attaining immunity was acceptable, the reasons might not. In Ex p. Mackay, the only discernible reason for the extra security was the desire of the creditor to better his own position in his debtor's insolvency. Other creditors suffered harm without receiving any compensating benefit.

${ }^{94}$ See e.g. [1975] 1 W.L.R. 758, 761F-G, 762D-763C.

95 That was almost certainly the case; it follows that the IATA scheme should have been upheld. Parliament seems to have taken a somewhat similar view; see Companies Act 1989, Part VII, which reversed the effects of the decision with respect to financial markets. The Act creates 
sufficient but not necessary condition, since the initial distribution scheme provided by the liquidation regime is not self-evidently appropriate and therefore must itself be argued for.) The pari passu red herring served massively to confuse this issue. In failing to consider it clearly, it is submitted the British Eagle decision is deeply unsatisfactory. ${ }^{96}$ Be that as it may, for the reasons discussed, the leading modern authority on the pre-eminence of the pari passu principle actually stands more for its hollowness than its hallowedness.

Ex parte Barter; Ex parte Black ${ }^{97}$ is another interesting decision cited in support of the pari passu principle. $^{98} \mathrm{X}$, a Portuguese steamship company, entered into an agreement with $\mathrm{Y}$, who were shipbuilders. Under the agreement, $\mathrm{Y}$ were to build and sell to $\mathrm{X}$ a steamship, the price for which was to be paid in instalments as the construction work progressed. On payment of the first instalment, the agreement provided that the steamship, its engines, and all associated materials were to be vested in $\mathrm{X}$, the buyers (the Court of Appeal referred to this as the "vesting clause"). It was also agreed that $X$ would have the right to seize all these materials if the construction work remained discontinued for a specified period, or if the ship was not delivered on time, or if $\mathrm{Y}$ became insolvent or bankrupt (the "seizure clause"). Finally, the agreement stipulated that, if any of the events mentioned above should occur, X would have the right to employ alternative builders to complete the ship, and to use Y's shipyard, premises, machinery, plant, tools and any other materials present on Y's premises suitable to the purpose (the "user clause"). The work commenced and the first instalment was paid. Subsequently, on Y's insolvency, $\mathrm{X}$ exercised its rights under the "seizure clause" and took possession of the ship, engines and related materials. This was upheld by the Court of Appeal: X was merely seizing property which already belonged to it by virtue of the "vesting clause".99 However, the "user clause" was struck

\footnotetext{
yet another exception (if the British Eagle decision were to be taken at face value) to the "equality" principle. The recent decision of Neuberger J. in Money Markets International Stockbrokers Ltd. v. London Stock Exchange and Another (Transcript, 10 July 2001), recognises yet another exception to the principle, this time concerning property the ownership of which depends on the personal characteristics of the owner, and further, assets so inextricably linked to such property that they could be considered "ancillary" to it (see e.g. paras. 110-113). In this case, these were, respectively, the membership of the London Stock Exchange, and a " $\mathrm{B}$ ' share" entitling the holder (roughly) to vote on decisions about how the company which owned the Exchange was to be run, and to participate in the distribution of the value released because of that company's demutualisation.

${ }^{96}$ See Goode's misgivings about the decision, Insolvency, pp. 181-182, and those of Oditah, "Assets", p. 466. For an uncritical invocation of the decision in favour of the "equality" principle, see Finch, "Pari passu", pp. 198, fn. 28 and 199-200.

97 (1884) 26 Ch.D. 510.

98 See Oditah, "Assets", p. 464, fn. 36.

9926 Ch.D 510, 518-519 (per Fry L.J., delivering the Court's judgment).
} 
down, since "a power upon bankruptcy to control the user after bankruptcy of property vested in the bankrupt at the date of the bankruptcy is invalid". ${ }^{100}$

The Court's decision is hardly surprising, in view of the extravagance of the terms of the "user clause" if for no other reason. But in any case the relevant issues are very clear on the facts. We must note the two most important points. First and yet again, there was no absolute bar to the parties bargaining for immunity from the collective regime. This was quite obviously the effect of the "vesting" and "seizure" clauses. Instead of lining up with the rest of Y's creditors and submitting to the collective decisions made by $\mathrm{Y}$ 's trustee, $\mathrm{X}$ was able to remove itself from the queue to the extent of the value of the materials covered by the two clauses. But second, the "user clause" was an attempt to commandeer Y's remaining estate for the sole benefit of $\mathrm{X}$, removing that too from the ambit of the trustee's decision-making. This was regarded as unjustifiable. Even as to the "user clause", $\mathrm{X}$ had argued that it would redound to the general good of all of Y's creditors, since the completion of the ship would reduce pro tanto the amount for which $\mathrm{X}$ would prove in the bankruptcy for Y's breach of contract. ${ }^{101}$ The Court of Appeal disagreed: in the absence of the clause, the trustee would have decided whether to complete the ship and claim the contractual price, or to abandon the contract, and this decision would have been made for the benefit of all of Y's creditors. But the "user clause" removed the trustee's ability to make that choice, and instead vested that choice in $\mathrm{X} .{ }^{102}$ To the extent to which $\mathrm{X}$ was a creditor for damages for Y's breach of contract, the clause purported to grant $\mathrm{X}$ immunity from having to participate in the collective bankruptcy regime. This attempt to gain immunity was regarded as unacceptable.

Now whatever one might think of the distinctions made in the Court's judgment about acceptable and unacceptable ways of bypassing the collective regime, we should note once again that the pari passu principle was not at issue. The "user clause" would have by-passed the inequality of the regime (inherent in the rules governing set-off, pre-preferential and preferential claims etc.) before it evaded its "equality". The crucial issue was not X's place in the queue relative to other creditors but the fact that he would not have had to queue up at all, and-if that was not enough- 
would have prevented the trustee being able to make a collective decision about much of the remaining pool of assets. ${ }^{103}$

The same point can be made again and again. Cases cited in support of the "equality" principle either support that principle only as part of a significantly "unequal" insolvency regime, or more frequently, show nothing except the law's intolerance towards attempts to gain immunity from the collective liquidation system in unacceptable or unfamiliar ways. In view of all this, the pari passu principle could not possibly be necessary for there to be an orderly liquidation. In addition to all the arguments above, to the extent that the current liquidation regime is accepted as fulfilling the requirements of orderliness and as replacing the value-destroying rush for an insolvent's assets, and given that pari passu is a very partial feature of the system, the present liquidation regime itself constitutes a rebuttal of any such claim. ${ }^{104}$ What is more, the very significant departure from this principle represented by insolvency set-off has been regarded at the highest judicial level as itself necessary for a "proper and orderly" administration of the estates of insolvent companies. ${ }^{105}$ But then, since "equal" treatment of different types of claim is not required to gain the practical advantages associated with the orderly winding up of insolvent estates, and since it is not necessary to justify insolvency law's peculiar features (e.g. its collectivity, and the avoidance of preferences and post-petition dispositions), the existence of differential priority-including that of secured creditors - cannot be impugned on the ground that it interferes with the attainment of these goals.

Finally and in the interests of completeness, a decision which allows parties to bargain for a priority different from the one they would have had without that agreement-but without allowing

${ }^{103}$ Ex p. Jay (1880) 14 Ch.D. 19 is a similar case, and is cited by Goode, Principles, p. 151, fn. 39 and Oditah, "Assets", p. 464, fn. 36, as an application of the "equality" principle. Here, $\mathrm{X}$ attempted to vest the title to portions of Y's estate (and not merely the use, as in Ex p. Barter) in herself on Y's bankruptcy. This was struck down, but the reason was (as discussed) the unacceptable attempt to circumvent the operation of the collective regime. With respect, the pari passu rule simply was not relevant to the decision one way or the other.

${ }^{104}$ It would be otherwise if the claim were that the liquidation system could not be "orderly" in the appropriate sense to the extent that it diverges from an "equal" distribution. But such a claim would be trivial, and would amount to saying that, to the extent that the system diverges from the pari passu principle, it diverges from the pari passu principle! None of the commentators cited above in support of the principle seem to be taking that position, and all of them seem to accept that the current liquidation regime (despite its less-than-perfect adherence to the pari passu ideal) at least provides a fair degree of order to the process of winding up insolvent estates.

105 National Westminster Bank Ltd. v. Halesowen Presswork Ltd. [1972] A.C. 785, 809A, per Lord Simon; to similar effect but expressed with greater reservation, see the view of Lord Kilbrandon, pp. $822 \mathrm{C}$ and $824 \mathrm{~A}$. For the proposition that insolvency set-off exists, not to further any such general purpose, but only for the benefit of the party having mutual dealings with the bankrupt, see the sole dissenting speech of Lord Cross, ibid., pp. 812-813. 
immunity from the rules of the liquidation regime-is Re Maxwell Communications Corporation. ${ }^{106}$ This case concerned an agreement whereby certain bonds issued by M Ltd. (held by parties referred to hereafter as "the Bondholders") were guaranteed by $\mathrm{M}$ plc. "on a subordinated basis". Subsequently, M Ltd. being insolvent, M plc. was placed in administration. The administrator applied for an order to exclude the Bondholders from participation in a scheme of arrangement under which, secured and preferential creditors having been paid, the remainder would be distributed pari passu among M plc.'s other unsecured creditors. In accordance with the subordination agreement, the Bondholders would only be paid if these other unsecured creditors were first paid off in full. It was clear on the facts that, if this scheme was approved, the Bondholders would get nothing. ${ }^{107}$

It was argued on behalf of the Bondholders that the subordination agreement was void as being in breach of the pari passu principle: "the liquidator ought not to be required or entitled to look behind a proof to determine whether a creditor submitting a proof was entitled to payment pari passu with other unsecured creditors". ${ }^{108}$ In effect, the submission was that the pari passu principle should be given effect with respect to all those general creditors who submitted a proof, the liquidator being required to turn a blind eye to the pre-insolvency dealings between the debtor and (some of) its creditors. This was rejected. Vinelott J. pointed out that "[t]here are situations under the Insolvency Act 1986 in which an unsecured debt is postponed to other unsecured debt" ${ }^{109}$ In these situations, the liquidator might well need to have regard to the pre-insolvency status of different unsecured creditors. So if the liquidator had no difficulty in determining the pre-insolvency positions of various unsecured creditors and giving effect to statutory subordination, he would face no greater hurdle in dealing with contractual subordination. ${ }^{110}$ The judge read British Eagle as laying down the rule that "a creditor cannot validly contract with his debtor that he will enjoy some advantage in a bankruptcy or winding-up which is denied to other creditors". However, he held that this did not preclude an agreement between A and B Ltd. for the latter's debt to A to be subordinated in B's insolvency to that owed to B's other unsecured creditors. ${ }^{111}$

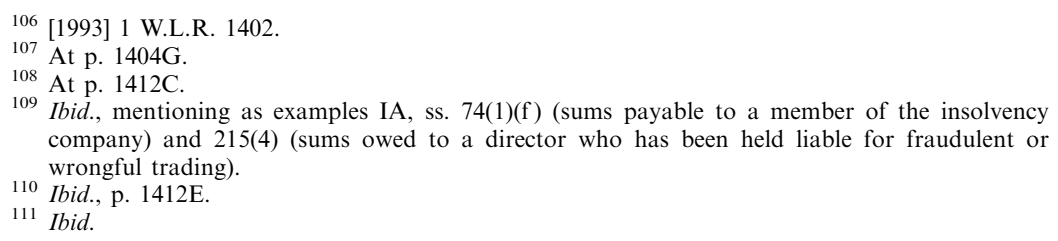


This decision should make it clear that the pari passu principle is far from sacrosanct. It is obvious that Re Maxwell allows parties to avoid it. The Bondholders, who would have ranked pari passu with M plc.'s other creditors, were relegated because of the terms of their agreement with $\mathrm{M}$ plc. to a position inferior to those other creditors. But this aspect of the decision should not tempt one to the hasty conclusion that the inexcludibility confirmed by British Eagle "applie[s] only to those rules the infringement of which would give one creditor an advantage denied to other creditors". ${ }^{112}$ Resorting once again to the analogy of the common pool, this would amount to saying that, the rule is that, within the insolvency regime, one can contract out of one's assigned place in the queue if the result would be to benefit the remaining unsecured creditors in the debtor's insolvency, ${ }^{113}$ but not if it would make them worse off. But this interpretation would be quite inconsistent with the House of Lords' judgment in Natwest v. Halesowen. ${ }^{114}$ That case shows one is not allowed to change one's place in the queue for the pool of the insolvent's assets simply because that would increase the bankruptcy value to be distributed to the remaining creditors. As already noted, the Lords there struck down an agreement which, by altering a creditor's priority position, would have brought about just such an increase. ${ }^{115}$

So when should parties be allowed to change their priority position within the collective liquidation regime, in other words, to alter their relative places in the queue to the pool of the insolvent's assets? Only a hint can be provided here. Most obviously, an agreement to alter the priority position of creditors within the liquidation regime should be allowed when - for all the creditors whose priority position in their debtor's insolvency would be made worse off because of the agreement - the expected benefits of the agreement to those same creditors outweigh its expected costs. ${ }^{116}$

112 Goode, Insolvency, p. 146, does reach that conclusion. He refers to Natwest v. Halesowen rather than British Eagle, but for the reason discussed in the text immediately below, this is almost certainly an oversight.

113 That the Re Maxwell decision has this effect is noted by Goode, Insolvency, p. 146, fn. 19.

114 See the discussion of this case above.

115 The creditor, National Westminster Bank, would have been deprived by the agreement of its ability to combine two accounts of the insolvent, and to set off the insolvent's liability to it on the overdrawn account against the credit balance in the other. Needless to say, the judicial disapproval of the agreement resulted in the Bank's having priority over the insolvent's other creditors to the extent of the amount set off.

${ }^{116}$ For an illustration, see Re Maxwell Plc. [1993] 1 W.L.R. 1402 itself, at p. 1416F-H. It would often be the case that a troubled company can only mount a rescue attempt if some of its existing creditors (EC) create an incentive for outside financiers (new creditors or NC) to lend to the company, by agreeing to subordinate their (EC's) claims to those of NC, should the debtor company be liquidated. The loss in insolvency value to EC resulting from the subordination agreement is outweighed by the benefit to them of the increased possibility that the company would be able to avoid liquidation altogether with the help of the funds injected into it by NC. See also Re Portbase Clothing Ltd. [1993] Ch. 388. For the reasons 
This again is a sufficient but not necessary condition, and is discussed further in the next Section.

\section{FAIRNESS AS "EQuALity"}

We have considered - and rejected - the claim that the "equality" principle is essential for the orderly liquidation of companies, and that it underlies important and distinctive features of the collective insolvency regime. This Section challenges the other main role often assigned to it. The pari passu principle requires that all creditors (in positions of relative equality as determined by pre-insolvency law) should be paid back the same proportion of their debt in their debtor's liquidation. Since this type of "equality" represents fairness, runs this argument, the pari passu rule ensures all creditors are treated fairly. Keay and Walton are of the view that "[t]he underlying aim behind the use of the equality principle is to produce fairness, so that every creditor is treated in the same way". ${ }^{117}$ As noted above, they argue that to abolish this principle would be to return to the "mediaeval" policy of allowing those with the greatest resources and power to deprive poorer and weaker creditors of anything in their debtor's insolvency. ${ }^{118}$ This would be normatively unattractive. Several other commentators have suggested in a similar vein that the "equality" principle enshrines fairness in liquidation. ${ }^{119}$

The debate about equality as a political ideal is long and complex. ${ }^{120}$ There is no question, in an article of this nature, of doing justice (as it were) to the issue of the type of equality, if any, that should be enshrined in a law-or the law as a whole-as

given in Goode, Insolvency, pp. 170-171, which are consistent with the analysis in this Section, it is respectfully suggested the Portbase decision is quite unsatisfactory.

117 "Preferential debts", pp. 93-94, including the references in fn. 78.

118 Ibid., p. 95.

119 See e.g. Finch and Worthington, "Pari passu", p. 3; Finch, "Pari passu", p. 194, noting another "traditional justification" of the principle; John McCoid, "Bankruptcy, preferences, and efficiency: An expression of doubt" (1981) 67 Virginia L.R. 249, 271; Thomas Ward and Jay Shulman, "In defence of the Bankruptcy Code's radical integration of the preference rules affecting commercial financing" (1983) 61 Washington University L.Q. 1, 16. For a rather more nuanced approach which still regards the "equality" principle as the default rule, see Korobkin, "Contractarianism and the normative foundations of bankruptcy law" (1993) 71 Texas L.R. 541, 601-602 and 607-609. See also John Farrar, "Public policy and the pari passu rule" [1980] N.Z.L.J. 100, who mentions the argument that it would be unfair for some creditors to be allowed to contract out of the liquidation regime (not just the "equality" principle), but finds it "questionable", sometimes even "wide of the mark"; see p. 100 .

120 For just two opposing views, see Ronald Dworkin, Sovereign Virtue: The Theory and Practice of Equality (Harvard University Press, Cambridge, Mass., 2000), and Joseph Raz, The Morality of Freedom (Oxford, Clarendon, 1988), Ch. 9. A very useful overview of the issues is found in Gosepath, "Equality", in Zalta (ed.), The Stanford Encyclopedia of Philosophy; $\mathrm{URL}=\mathrm{http} / / /$ plato.stanford.edu/entries/equality/. For the reasons given there (see esp. Section 5) and others, it is submitted that Raz's attack on equality as a distinct political and moral virtue is simply untenable. 
representing fairness. This is especially true when, as here, the notion of "fairness as equality" is only one of several issues to be considered. So the discussion here will be a summary one. However, it is suggested that even this should suffice, at the very least, to cast serious doubt on the claim that the pari passu principle conduces to fairness in liquidation.

There can be no doubt that real equality is a-some would say the only-form of fairness. But a set of laws enshrines real equality only when it treats all those subject to it as equals. However, "[t]here is a difference between treating people equally, with respect to one or another commodity or opportunity, and treating them as equals". ${ }^{121}$ It is this crucial distinction which is universally overlooked by supporters of the pari passu principle.

Let us distinguish, in a rough and ready way, between formal and real equality. In the relevant context, formal equality holds when the same rule applies to all people. That everyone must stop at a red traffic light is an example. This type of equality, while undoubtedly important, results in a fairly superficial form of fairness, the limits of which are easy to expose. It is not obviously fair to insist that an ambulance should be obliged to wait at the red signal just like any other vehicle, even though carrying a seriously ill patient. That access to a building is provided "equally" to all by way of a steep staircase does not necessarily prevent those using wheelchairs from being treated unfairly. Or think of a flatrate income tax: regardless of how much you earn, let us say $25 \%$ of your annual income is to be paid over to the state. Many (perhaps most) readers would intuitively find this method of taxation normatively unappealing. That you are to be deprived of the same proportion of your income, whether you earn $£ 10,000$ or $£ 10 \mathrm{~m}$ per annum, would not strike them as particularly fair. Note here the parallel with the pari passu rule, which represents the decision that all creditors are to be deprived of the same proportion of their debts, should their debtor become insolvent. The problem is that a rule based on formal equality does not take into account important differences between people, even though those differences are relevant to any consideration of the rule's fairness. Of course equals must be treated as equals, but who is to be considered equal to whom, and in what respect? Merely formal equality might resolve these vital questions by reference to trivial, or irrelevant, or meaningless attributes. But for equality to result in fairness (a morally charged concept), the determination of who constitutes an equal must be based on characteristics that

${ }^{121}$ Dworkin, Virtue, p. 11. 
themselves are morally significant. So a rule based on formal equality is often empty of normative content. To treat people with only formal equality is frequently not to treat them as equals.

How do we treat people, then, in order to treat them as equals? One attempt to describe what this entails in the specific context of corporate insolvency is the Rawlsian framework of the Authentic Consent Model. ${ }^{122}$ The Model suggests parties are treated as equals - and thus fairly - when their respective interests are accorded equal care and respect in the selection of insolvency law principles. Space does not allow a fuller treatment of this Model here. However, the discussion which follows should be regarded as flowing from the considerations identified as relevant in it, and from the methodology it enshrines. Let us consider the proposal that in order to ensure fairness in the distribution of assets in a corporate liquidation, all those who hold a claim which noninsolvency law determines to be formally similar, are to get back the same proportion of what they are owed. It is suggested that in this general form, this proposal is unacceptable. The reason is straight-forward. Non-insolvency law does not need to determine the priority status of different types of creditor, since for most solvent debtors, all creditors get everything they are owed. ${ }^{123}$ For that reason, non-insolvency law makes few formal distinctions between various types of claimant. The unsecured claim of a bank, a tax liability owed to the Crown, and the unpaid wages of an unskilled worker, all have the same pre-insolvency form. Noninsolvency law often does not resolve an issue which is (almost by definition) peculiar to insolvency itself - who should bear how much loss when a company is rendered terminally unable to meet its obligations? ${ }^{124}$ So when an actor does become insolvent, to seek guidance from non-insolvency law to determine how different claimants ought to be treated - as the pari passu principle purports to do-is to commit the old formalist error identified above. The "equality" principle determines who counts as an "equal" by reference to an attribute of the claimants (i.e. the non-insolvency form of their claim) which is irrelevant or trivial or meaningless as regards the appropriateness of any method of distribution of an insolvent's estate.

This point can fruitfully be explored further. Let us isolate the issues of interest to us by making two assumptions. First, suppose there are only three types of creditor, commercial banks, the

\footnotetext{
122 Worked out at some length in Mokal, "Authentic Consent".

${ }^{123}$ This point is made by Goode, Insolvency, p. 39.

124 There are some exceptions, most notably the status of secured claims. But even here, insolvency law must consider whether to take account of the pre-insolvency form of the claim for meaningful reasons, not because it fetishizes form. This is touched upon below.
} 
Crown, and the debtor's employees. ${ }^{125}$ And second, pretend that the bankrupt's estate must be allocated without reference to the parties' own pre-insolvency interests and commitments. ${ }^{126}$ Now it is obvious that banks lend to thousands of companies (or more) and are therefore well-diversified. Banks can balance the harm of receiving somewhat less in the insolvency of some of their debtors, against the profit they make from lending to the many more who pay back every penny with interest. By virtue of being repeat players, they have accumulated expertise in assessing the creditworthiness of their borrowers. And since they are strong commercial players in an under-diversified market for the provision of credit, ${ }^{127}$ they have a strong influence on the terms on which they lend. So bank-creditors are very well-placed to deal with being paid back less than they are owed in any individual insolvency.

On the other hand, employee-creditors might often be dependent solely on their salaries, might be unable to diversify by working for more than one employer, might have no insurance because they are not able to join a trade union which would buy such insurance for its members, might have had no influence over the terms on which they were employed and therefore became creditors, and might be unable quickly to find work on being deprived of a job by virtue of their employer's insolvency. ${ }^{128}$ Employees might be owed wages for several weeks or months, having supplied services to their company while it was in financial distress without demanding payment on time, in the hope that the company would recover. Such employeecreditors might suffer serious detriment if they lose too great a proportion of their outstanding debts.

Viewed thus, the suggestion that bank-creditors and employeecreditors should both be treated "equally" by being paid back the same proportion of what they are owed, seems absurd. That the two types of creditor hold claims judged under non-insolvency law to be formally similar to each other does not carry too much weight. To treat these parties as equals in their debtor's insolvency requires that those in a more vulnerable position in their debtor's insolvency be given greater protection than those better able to deal with the loss. Fairness does not result from treating the two types of creditor "equally", so the pari passu principle - stated broadly as

${ }^{125}$ We also ignore for the moment the employee-creditors' rights under the Employment Rights Act 1996. That is discussed in the next Section.

126 For two reasons, this assumption must be treated with the greatest caution. First, it is difficult to sustain coherently and without self-contradiction. And second and despite this seemingly fatal feature, it has been unconsciously accepted and been the cause of many problems in insolvency scholarship. Both these points are touched upon below.

127 Don Cruikshank, Competition in UK Banking (HMSO, 2000), pp. 149 and 155.

${ }^{128}$ See e.g. Mokal, "Authentic Consent", Section 12; and Keay and Walton, "Preferential", pp. 95 and 99 ; but see also pp. 100-101. 
above-should be rejected outright as applied to bank- and employee-creditors with claims similar to each other under noninsolvency law. It is submitted the same reasoning holds mutatis mutandis for the various types of creditor different in this morally significant way, regardless of the formal legal nature of their claims. So for example, the principles of distribution resulting from this exercise are more likely to give employee-creditors at least a degree of priority in their employer's insolvency over most other types of claimant. $^{129}$

It should be emphasised that the extent to which creditors are vulnerable to serious harm in their debtor's insolvency is only one of several relevant considerations in determining their proper ranking in corporate liquidation. The point here is not to identify all such factors (or even to defend the preferential debts regime as it stands today), but rather, to cast doubt on the pari passu principle as the guardian of fairness in liquidation. It should be obvious its crude "equality" is almost entirely unattractive if we wish to treat all the parties as equals.

This concludes the argument that the pari passu principle has nothing to do with fairness. But to leave this discussion at this point would be profoundly misleading. Recall the second assumption made above, that in choosing principles to govern distribution of an insolvent's assets, we are unconcerned about the parties' pre-insolvency rights and obligations. This assumption allowed us to focus narrowly on whether "equality" of distribution in corporate liquidation is normatively attractive. But while useful for that purpose, it is problematic and of course totally counterfactual. Creditors of a firm which becomes insolvent do not suddenly develop a completely new set of interests without link or connection with the interests they had before this particular debtor became unable to pay its debts. In their capacity as actors on the commercial stage, they do not undergo a re-birth which purges them of pre-insolvency commitments. Their interests and obligations within liquidation flow from their pre-liquidation ones, and are inextricably linked. So for example, to accept the very existence of claims against the now-insolvent company is to acknowledge this inseverable link with the pre-insolvency commitments of the actors. And one of the reasons why employees are more deserving of protection in their employer's insolvency is their pre-insolvency inability to diversify, and (for many employees) to have an appreciable say about the terms of their employment, etc.

129 Compare IA, s. 175 (and s. 386), and Sch. 6, which create a priority regime for (inter alia) employee-creditors. This supersedes the "equality" principle enshrined in e.g. IA, s. 107. 
It follows that, while the pre-insolvency form of claims might not matter, the pre-insolvency interests and obligations of all the parties must always be taken into consideration when deciding about the priority of certain types of claimant over others. Fairness demands that each claimant be accorded equal care and concern. But this involves looking at the totality of the interests and obligations of each. So the principles of insolvency law, though dealing exclusively with peculiar insolvency issues, should not focus exclusively on the interests of parties once a relevant actor is already insolvent. Rather, they should affect the parties in a way which pays equal attention to both their pre- and post-insolvency interests and obligations, conceived of as the continuities that they actually are. So the distributive principles of insolvency law should uphold any pre-insolvency priority arrangements which, for example, serve the entirety of the interests of each of them. This despite the fact that those arrangements do not serve the post-insolvency interests of some of them. One of insolvency law's more challenging tasks is therefore to distinguish between pre-insolvency priority arrangements which are mutually advantageous to all the relevant parties, and those which are merely exploitative. The latter must of course be ruled out, but it would conduce to fairness actually to give effect to the unequal distribution resulting from the former. ${ }^{130}$

\section{The Proper Role of "Equality"}

The argument so far has concentrated on what the pari passu principle in particular, and formal equality in general, do not do. It would perhaps be useful to add a word here about what in fact their actual role is. Formal equality operates in three types of situations in liquidation, always for the same reason. First, let us consider the pari passu principle itself. Commonly understood as governing the claims of general unsecured creditors, it is submitted that this is not primarily a rule of distribution at all. On the contrary, it is a rule of non-distribution. The argument here can be broken down into four steps.

First, certain types of claim are considered "important", in the sense that they should be met to a significant degree in most insolvencies. To ensure this is the case, they are allotted special priority positions, either by the parties to commercial transactions, or (where the parties cannot be trusted to reach the right result) by Parliament itself. Second, not to provide a particular priority position for a type of claim is to ensure it will receive little or nothing in most insolvencies. Third and following from that, there

${ }^{130}$ The question whether ordinary security arrangements are exploitative is left for another day. 
must still be a fall-back provision which covers the treatment of these latter claims. In view of the paucity of value to be distributed to those holding such claims, it is especially important that the implementation of this fall-back provision in individual liquidations should be cost-effective. Fourthly and finally, the conclusion is that the pari passu principle is the ideal fall-back provision. This is the basic structure of the argument, and it must now be fleshed out.

Let us begin by noting once again that in any formal insolvency proceeding, different claims are treated according to different priority rules, depending both on who holds those claims, and what sort of assets the claims are being applied to. Creditors able to assert set-off rights created and mandated by insolvency law beat all others to the extent of those rights. For assets subject to fixed charges, the chargee of course ranks first. ${ }^{131}$ For trade goods supplied under an acceptable ROT provision, the trade creditor can reclaim them. For goods subject only to a floating charge, postliquidation claimants rank ahead of preferential creditors who rank ahead of the floating charge holder, and so on. All these priority rules are thought to have different rationales. For example, insolvency set-off is said to be based on consideration of fairness. ${ }^{132}$ The priority of (some) secured creditors, and of trade creditors with ROT's, arguably stems from strong efficiency considerations and is mutually advantageous to all. ${ }^{133}$ Post-liquidation creditors are given precedence because they cannot be expected to subsidise preexisting claimants. Preferential creditors are said to be worthy of special treatment because they do not choose their debtor in any meaningful sense, do not negotiate the terms of their loans, and (in the case of employees) might be undiversified. ${ }^{134}$ The list goes on. The different priority rules are all complex. It takes time, resources and effort for Parliament on the one hand, and debtors and creditors themselves on the other, to decide what types of claim should rank in what order, with respect to different types of asset.

Of course, however, the state of insolvency is by definition one where the debtor cannot fulfil all its obligations. (As already suggested, priority rules are really crucial only against this background of insolvency.) What we would regard as general unsecured claims, then, are those for which neither Parliament nor

${ }^{131}$ Except in the charge-back situation, where consistency demands that the party able to assert set-off rights should be given precedence; see Mokal, "Resolving".

132 For example, see ibid., p. 112, fn. 40 and the accompanying text.

133 There is a vast literature on the subject. See especially Steven Schwarcz, "The easy case for the priority of secured claims in bankruptcy" (1997) 47 Duke L.J. 425; for reasons similar (but not identical) to those he suggests, the priority of secured creditors is beneficial for all the parties collectively. Further discussion is beyond the scope of this paper.

${ }^{134}$ See above; see also the discussion in Keay and Walton, "Preferential claims", who argue against elevating the Crown and employees to preferential status. 
the parties themselves have provided specific rules of distribution. This must be viewed in the context that generally, only secured, post-liquidation and preferential creditors get anything in their debtor's insolvency. There is little or (much more frequently) nothing for those ranking below them. So the interests regarded as more worthy of attention (and therefore arguably more important) by the rule-makers (public and private) are given precedence with respect to particular types of asset, in certain situations, to a specified extent. To decide not to provide for such a priority for a type of claim is in fact to decide not to have it met at all in most insolvencies. And it is this reasoning which provides the crucial insight into the true role of the "equality" norm. It was suggested above that pari passu should not be viewed as a default rule. It cannot accurately be regarded as the starting position, departures from which must be explained. Instead, it is now submitted, the rule is best seen as a fall-back provision. It is the rule which takes over when it would be pointless to provide any other.

Here is the argument again. Some types of claim are regarded as important, and rules are provided to govern how they should be dealt with in insolvency. But once this is done, nothing (or not much) would be left for distribution to other creditors. Recall that most insolvency proceedings ( $75 \%$ of them or more) yield nothing for general unsecured creditors. And when they do bring some returns, the yields are fairly small (about 7 pence on the pound on average). So there simply is no point in deciding how these claims should rank vis-à-vis each other. For such claims to be governed by the pari passu rule makes very good sense, since the costs in terms of time, effort, and resources required to determine their appropriate (fair and efficient) rankings would far exceed any benefits. Why waste resources identifying and laying down different priorities, when it is obvious hardly any assets are likely to be distributed according to them? For such a situation, in fact, "equal" treatment is ideal. In most instances, this simply means some types of creditor equally get nothing. In the remaining minority of insolvencies, the tiny amounts available for distribution are all distributed proportionately, rather than being wasted in ascertaining the claimants' correct rankings. The pari passu principle applies, then, whenever the costs of providing for different rankings for different claims would exceed the benefits. The claims it governs mostly-and necessarily-constitute something approaching a distributively null set; they are held by those who will not receive anything. If they do receive something, it would not be much. It is for this reason that the "equality" principle is most accurately regarded as a rule of non-distribution. 
Now for the second application of formal equality in corporate liquidation, which lies in the treatment of the same "type" of claimant. For example, claims of all employees are treated "equally" and given preferential treatment over most other unsecured creditors. It was argued above that employees might be more deserving of protection in their employer's insolvency than other types of creditor, since they are more vulnerable to greater harm in these circumstances. But of course this is not equally true of all employees. It is not obvious that computer engineers, software designers, commercial lawyers, and others with scarce skills are in need of the same protection as unskilled workers. And one Information Technology expert might be much better placed to deal with the insolvency of his employer than another, perhaps because the former is younger and therefore considered more (re-) employable in that young industry.

But it makes sense nevertheless to treat all of them the same, simply because it would be too expensive to require the liquidator to investigate the relative positions of all the claimants in terms of vulnerability to serious detriment. What is more, it would be next to impossible for him to determine whether a particular employee was more vulnerable than others in this insolvency because, for example, he had been less cautious in planning for such a contingency than all the others, or because he had more expensive tastes for consumables like holidays, etc. ${ }^{135}$ Most liquidators asked to embark upon such an exercise would necessarily exhaust all available assets along the way, and no one would get anything. Apart from being inefficient, wastage of this nature does not lead to fairness either. Again, then, "equality" is resorted to because the costs of employing any more appropriate method of distribution (including one which is fairer in the abstract) would outweigh its benefits. $^{136}$

The third manifestation of formal equality has already been mentioned. Preferential claims are also treated "equally" inter se. It is interesting to note that even here, the reason behind this seems to be exactly the same. Notionally, of course, employees and the Crown are the two types of preferential claimant. But the employees of an insolvent firm, in recognition of their especially

135 These factors would be relevant for determining the appropriateness of any method of distribution according to any of a number of theories of fairness.

136 The limits on how much of the sums owed to employees rank as preferential debts can be seen as a more cost-effective way of ensuring that only the most vulnerable would truly benefit from the preferences regime; for details of these limits, see Keay and Walton, "Preferential", pp. 91-92, including fn. 54. The law of diminishing returns suggests that the more vulnerable the claimant, the more important it would be for him to receive even a smaller sum, and vice versa. The implications of this law seem not to have been noticed by Finch; see "Pari passu", p. 209. 
vulnerable position, have been accorded rights which - in their capacity as creditors - make them almost unconcerned about their employer's insolvency. This is because of the provisions of what is now the Employment Rights Act 1996 (ERA). This regime "provides for different and generally more extensive protection for an employee than under the Insolvency Act". ${ }^{137}$ Under it, the Secretary of State, through the Redundancy Payment Service, makes payments to employees from the National Insurance Fund. The ERA scheme covers (inter alia) up to eight weeks of unpaid wages and salaries, wages during the statutory minimum notice period, up to six weeks of holiday pay, and a basic award for unfair dismissal. These payments are likely to be larger than those given preferential status by the Insolvency Act. For the payments made, the Secretary of State is subrogated to the employees' rights. $^{138}$

Relevant to our discussion is the fact that, "once employees' rights under ERA are factored into the overall picture ..., the Crown, by subrogation, takes over the claims of employees in a very large proportion of cases and is often the sole preferential creditor". ${ }^{139}$ Again, then, we have an excellent explanation (though historically perhaps a partial one) for the fact that preferential claims rank equally amongst themselves. Most of these claims are held by the same actor, the Crown. So again it would simply be pointless to provide for different priorities for these claims. Why expend resources differentiating these claims both ex ante and ex post, when in most cases any such differentiation would merely be notional? It is submitted that this provides further support for the proposition that formal equality in insolvency law (including that enshrined in the pari passu rule) is resorted to only when the costs of providing otherwise would outweigh the benefits. It is for this reason that the pari passu principle is best regarded as a fall-back provision. It is submitted that it plays no other role in insolvency distributions. ${ }^{140}$

Finally, it should be pointed out that even if analytically accurate, the arguments made in this Section are incomplete from a historical perspective. To meet this apparent deficiency, here is one hypothesis. The search costs for ascertaining optimum rankings for different types of claim depend either on the availability of a theory

137 Keay and Walton, "Preferential", p. 100.

138 For an account, see ibid., which this paragraph draws on.

139 Ibid.

${ }^{140}$ For suggestions which seem vaguely similar to the discussion here, see Finch and Worthington, "Pari passu", pp. 1 and 3; Finch, "Pari passu", 208-209, acknowledges a type of waste-prevention role for the "equality" principle, but seems to regard this as only one of its many virtues: see e.g. p. 194. 
of finance, or on a process of trial-error-adjustment by the parties themselves. When the former method is unavailable or underdeveloped, the time component of search costs (incurred during trial-error-adjustment) is high. So initially, only the more obvious methods of distribution (e.g. pari passu), and of bargaining for priority (e.g. rudimentary forms of security), which have therefore been developed earlier and employed for longer, would be cost-effective. So after 1543, when statute first provided for claims against bankrupts to be paid in "a portion rate and rate like, according to the quantity of their debt", ${ }^{141}$ this initially might in fact have been a rule of almost universal application, perhaps only secured and Crown claims being exempt. ${ }^{142}$ Again, this would have been so not because Parliament and the parties themselves at that time were fairer than they are now, but simply because no better method of distribution had then been discovered (i.e. none was cost-effective). But as better (fairer and more efficient) methods were discovered both through trial-error-adjustment and the development of theories of finance, pari passu would quickly be relegated to a mere fall-back provision even as applied to unsecured claims.

This hypothesis predicts that unless all creditors in real life are truly equal in all relevant respects, there would always be an increasing tendency for a fair and efficient insolvency law system to develop different priorities for different types of claim, to the full extent of all the assets generally available in liquidation. This then implies that attempts to "equalise" distributions to creditors who are different in relevant respects are thoroughly misguided, since they impede the development of a fairer and more efficient system.

\section{The Removal of Tax Claims Preferences}

The analysis in the previous Section allows us to examine the Government's recent proposal to remove the preferential status enjoyed by certain tax claims (discussed above). ${ }^{143}$ The proposal is conceived as "an important and integral part" of a package of reforms to corporate insolvency law, which also includes the

${ }^{141}$ See generally V. Markham Lester, Victorian Insolvency: Bankruptcy Imprisonment for Debt, and Company Winding-Up in Nineteenth-Century England (Clarendon, Oxford, 1995), Ch. 1.

142 See e.g. The Case of the Bankrupts (1584) 2 Co. Rep. 25a; 76 E.R. 441, 463-472. Note though that this decision seems partly to be based on the need to prevent a wrongly preferred creditor (and the debtor himself) being able to secure immunity from the collective bankruptcy regime; see pp. 473-474: it would be "a great defect in the law, if, after ... he hath utterly discredited himself by becoming a bankrupt, the law should credit him to make distribution of his goods to whom he pleased, being a bankrupt man, and of no credit; but the law ... hath appointed certain commissioners, of indifferency and credit, to make the distribution of his goods to every one of his creditors, rate and rate alike ..."

${ }^{143}$ See the White Paper, Insolvency - A Second Chance (The Stationary Office, 31 July 2001). 
abolition of administrative receivership and changes to the administration procedure to make it more "streamlined", and thus the successor to receivership. ${ }^{144}$ The White Paper suggests that in insolvencies where there is a floating charge, a certain proportion of the funds generated by assets subject to it would be "ringfenced" to ensure that the benefit of the proposed change goes to unsecured creditors rather than to the charge-holder. ${ }^{145}$ The Government predicts that the removal of tax claim preferences will bring "major benefits to trade and other unsecured creditors, including small businesses". ${ }^{146}$ Importantly, however, the "preferential status of certain claims by employees in insolvency proceedings ... within certain limits [also discussed above] will remain, as will the rights of those subrogated to them". ${ }^{147}$ It will be argued in this Section that the proposal to remove the preferential status of tax claims is unlikely to bring any significant benefit to unsecured creditors, and thus does not fulfil its stated objective. In addition, the proposal is incoherent.

In order to evaluate the proposal, we should begin by trying to estimate the quantum of the additional benefits to unsecured creditors which can be expected to result from its implementation. Even a very rough estimate requires a lengthy calculation, and, because of the imprecision of the data available, the estimate here will indeed be rough. But it will soon become apparent that this does not matter to the point being made here. Unless otherwise stated, any doubts in the figures are resolved so as to maximise the expected additional benefit to unsecured creditors from the proposed change.

At the moment, total liabilities of companies that undergo a formal insolvency procedure during a year are estimated to be about $£ 42$ b. ${ }^{148}$ Of this, about $35 \%$ is owed to banks. ${ }^{149}$ Let us suppose that $80 \%$ of bank debt is secured on the company's assets. ${ }^{150}$ So secured creditors are owed, roughly, $28 \%$ of the total outstanding debt. Preferential creditors get back about $30 \%$ of what they are owed. ${ }^{151}$ The amount actually paid out as dividends

144 Ibid., The Rt. Hon. Patricia Hewitt M.P., "Foreword", and "Corporate Insolvency Proposals", paras. 2.19, 2.2-2.6, 2.18, and 2.7-2.17.

145 Ibid., para. 2.19.

146 Ibid., "Foreword".

147 Ibid., para. 2.20.

148 ABRP, Survey, p. 11.

149 This comes from the calculation that, for the Franks-Sussman sample, banks were owed about $40 \%$ of total outstanding liabilities when firms entered the "central rescue unit" (see Cycle, p. 8), and, for that sub-set which eventually ended up in the "debt recovery unit" and hence in a formal proceeding, $12 \%$ of that debt was paid off while the firm was in the "rescue unit" (Cycle, p. 11).

${ }^{150}$ Ibid., p. 13, Table 8, gives the value of collateral as a percentage of bank debt; the figure in the text is an estimated composite.

151 Again, this is a composite figure derived from Franks-Sussman, Cycle, p. 3, and ABRP, Survey, p. 18. 
in right of tax claims preferences is around $£ 100 \mathrm{~m} .{ }^{152}$ So preferential tax claims themselves amount to some $£ 333 \mathrm{~m}$. The amount owed in right of employee preferences is an estimated $£ 200 \mathrm{~m} .{ }^{153}$ Altogether, then, preferential debts constitute about $1.3 \%$ of the total debts owed by insolvent companies. It follows that unsecured creditors are owed about $70.7 \%$ of the total outstanding debt of companies in insolvency proceedings. This amounts to around $£ 29.69 \mathrm{~b}$. They get an average of 7 pence on the pound, ${ }^{154}$ or about $£ 2.1 \mathrm{~b}(£ 2100 \mathrm{~m})$ today.

Now the Government estimates that the removal of tax claims preferences would bring "up to" $£ 100 \mathrm{~m}$ more for unsecured creditors. ${ }^{155}$ So after the removal of preferential status for tax claims, unsecured creditors will get $£ 2200 \mathrm{~m} .{ }^{156}$ In other words, their recoveries would go up to $7.4 \%$ once the proposal is implemented. This is of course an increase of less than one-half of one penny over what they currently get! And that does not take into account that all tax claims would then also rank alongside other unsecured claims. ${ }^{157}$

It should be obvious, then, that even if these calculations are wide of the mark (so that the actual increase will be twice, thrice, or even five times this much), the average recovery rates for unsecured creditors in an overwhelming majority of formal insolvency proceedings are unlikely to go up to the extent that such creditors would be appreciably better off. The Government's claim that this "important and integral" part of its reform package will bring "major benefits" to them therefore seems simply unsustainable. In addition, and in line with the analysis in the previous Sections, the reader should note that it makes very

${ }^{152}$ Second Chance, Annex D, para. 4.15. This figure is probably over-inclusive, in line with the practice here of resolving doubts in favour of maximising expected additional benefits to unsecured creditors.

153 The figure in the text has been increased to take into account the age of the data currently available, and might be an overestimate; see the National Audit Office Press Notice, "The Department of Trade and Industry Redundancy Payments Service: Management and Recovery of Debt" (17 October 1996); available at URL: www.nao.gov.uk/pn/9596695.htm (which mentions a figure of $£ 177 \mathrm{~m}$ ); see also Keay and Walton, "Preferential", p. 100, including fn. 131.

154 ABRP, Survy, p. 18.

155 Second Chance, Annex D, para. 4.15. Again, note the possible over-inclusivity of this figure.

156 These calculations are subject to the assumption that in deciding on the proportion of floating charge assets to be "ringfenced" for unsecured creditors, the Government will be true to its word that their proposed changes would not adversely affect the interests of secured creditors; Second Chance, para. 2.6.

157 Also ignored is the fact that the abolition of receivership would remove the costs of receiver "opportunism"; see Franks and Sussman, "Resolving financial distress by way of a contract: An empirical study of small UK companies" (22 October, 2000), p. 18; the paper is available at URL: www.ifk-cfs.de/papers/franks.pdf. However, these costs are relatively quite small, since they only arise in administrative receiverships, and then only in a proportion of those cases where the receiver's appointor is not fully paid. Their elimination is unlikely to make any noticeable difference to the result. 
obvious sense to subject to the pari passu rule the tiny additional sums which will become available in many formal insolvency proceedings because of the proposed change. For these additional sums, it would be entirely wasteful to attempt to think up some other set of priorities. The costs of doing that would be quite unjustified in view of the size of the expected benefits.

So much for the suggestion that the proposal is likely to be inefficacious. To understand why it is incoherent, we should recall that, because of the rights of employee-creditors of insolvent companies under the ERA, the claims apparently held by them and given preferential status, are mostly vested in the Crown by way of subrogation. So preferential tax claims and preferential "employee" claims are in most cases held by the same actor. Nor does this fact go unnoticed in the White Paper. As already mentioned, the Paper not only states that certain employee claims will retain their preferential status, but also explicitly includes within this reservation "the rights of those subrogated to them", ${ }^{158}$ or in other words, of the Crown itself. Now the supposed rationale for removing the preferential status of tax claims is presumably the well-rehearsed one that the Crown is better able to absorb the loss of not being paid by some of its debtors, than are some other categories of creditor, for example, weak trade creditors. ${ }^{159}$ But if this is accepted, it surely follows that "employee" claims, also generally held by the Crown, should lose their preferential status for exactly the same reason. Employees might deserve greater protection in their employer's insolvency than other types of claimant, but if they have already been reimbursed from the National Insurance Fund, then the competition is no longer between them and other unsecured creditors, but between the latter and the Crown. So there seems little sense in suggesting reform to only one category of preferential claims, when the reason why that reform is considered desirable is equally a reason to change the other category as well. This is especially relevant given that the stated aim of improving the prospects of unsecured creditors is expected to be fulfilled to a negligible degree in any case. ${ }^{160}$

At the very least, the Government bears the burden of showing what makes preferential tax claims different from most preferential "employee" claims. One way in which it might attempt to do so would be to provide better data than is currently available, and thus rebut the premise of this argument, that the Crown holds, by

\footnotetext{
158 Second Chance, "Corporate Insolvency Proposals", para. 2.20.

159 This is implied in the "Foreword" to the White Paper; in any case, no other rationale is suggested there.

${ }^{160}$ It should be noted the point being made here merely addresses the coherence of the proposal, not its overall desirability.
} 
subrogation, most preferential "employee" claims. But even then, the obvious solution would be to adopt the approach enshrined in the US Bankruptcy Code, which provides that an entity subrogated to the rights of, inter alia, the employee-creditors of a bankrupt company, is not entitled to enjoy the statutory preferential status provided to some of their claims. ${ }^{161}$ This would ensure that the preferential status of "employee" debts was retained only to the extent that employees themselves would benefit from it. Unless the Government explains why this is unacceptable, it seems difficult to avoid the conclusion that its proposal is based on an arbitrary and thus unjustifiable distinction.

\section{Conclusion}

Some years ago, Bridge concluded his brief review of the clash between pari passu distribution on the one hand, and the freedom of contract which allows parties to grant and take security on the other, by framing the issue thus: "Is the pari passu principle so strong that the burden of proving efficiency rests upon those who support secured credit, or is freedom of contract paramount so that the burden falls upon those who oppose security?"162 Even without invoking freedom of contract, ${ }^{163}$ here (it is submitted) is the answer. The first premise of those attacking the priority accorded to secured claims - that unequal treatment of claims is anomalous, somehow a deviation from the "strong" "equality" norm-is quite false. If anything, it is the pari passu principle which constitutes an isolated enclave of "equality" in a (formally) unequal insolvency world. In that real world, its status-considered as a rule governing distribution of assets-hovers somewhere between falsehood and tautology. So with respect, assertions that this principle is allpervasive in the liquidation regime, that it underlies some of the best-known avoidance provisions of that regime, or that it provides the only alternative to an undesirable free-for-all, all stand rebutted as based on a fallacy. They must all be abandoned. So must the argument that the pari passu principle is necessary to ensure fairness in liquidation.

It is submitted that it is the critics of differing priorities for different types of claim, including those attacking the full priority of secured claims, who must now be on the defensive, at least on these grounds. The general rule in insolvency law, its deeplyembedded norm, seems to be that the assets available in insolvent

${ }_{161}$ Section 507(d). Many thanks to Look Ho for drawing attention to this.

162 Bridge, "Quistclose", p. 342.

163 Since Parliament itself (and not just the parties in commercial transactions) has reduced pari passu to the sham that it is. 
estates are to be distributed "unequally", unless attempting to do so would be pointless because wasteful. It might be that the different priorities afforded to different types of claimant are sometimes arbitrary. It might be that this area of the law could do with extensive re-thinking and rationalisation. Even then, it would not follow that what should replace the current system is one which crudely equalises all creditors in their debtor's insolvency. Formal equality of that sort is not the natural alternative. It will not win by default. Not only is it rare and unnecessary in the real world, it is also useless as an ideal. So it must be argued for as much as any other system of priorities proposed as a replacement for the current one, and it would be at least as contentious as any of them. Those arguing for (a more) "equal" treatment of all claims must therefore bear the heavy burden of showing why moves towards formal equality are desirable. 